$(200)$

T6r

no. 349 .

\title{
Progress Report of \\ Southeastern Monazite \\ Exploration, 1952
}

By W. C. Overstreet; P. K. Theobald, Jr., A. M. White, N. P. Cuppels, D. W. Caldwell, and J. W. Whitlow

\section{Trace Elem ents Investigations Report 349}

UNITED STATES DEPARTMENT OF THE INTERIOR GEOLOGICAL SURVEY 


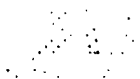

a d a d a

$\because \cdots$ 
Geology and Mineralogy

This document consists of 105 pageid. plus lis plates.

Series A.

UNITED STATES DEPARTMENT OF THE INTERIOR

GEOLOGICAL SURVEY

PROGRESS REPORT OF SOUTHEASTERN MONAZITE EXPLORATION, 1952*

By

W。C. Overstreet, $\mathrm{P}$ 。 $\mathrm{K}$ 。 Theobald, Jro, A。M。 White, N。P Cupples, D。Wo Caldwell, and J。Wo Whitlow

April 1953

Trace Elements Investigations Report 349

This preliminary report is distributed without editorial and technical review for conformity with official standards and nomenclature。 It is not for public inspection or quotation.

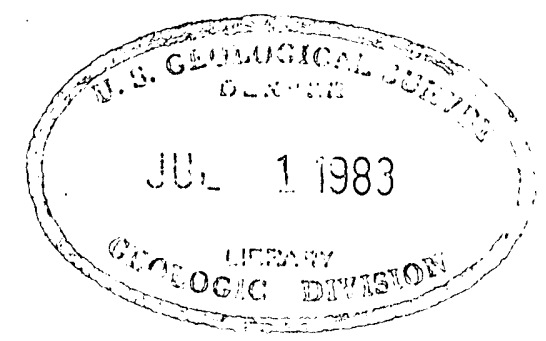

*This report concerns work done on behalf of the Division of Raw Materials of the U。 S。Atomic Energy Commission。 
Distribution (Series A)

No: of copies

American Cyanamid Company, Winchester . . . . . . . . I Ar.gonne National Laboratory 0.0 .0 .0 .0 .0 .0 .0 .01

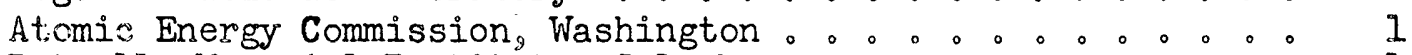

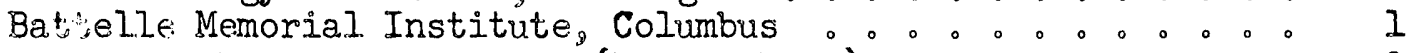

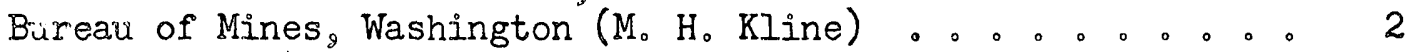
Carbide and Carbon Chemicals Company, Y-I2 Area . . 。 . - 1

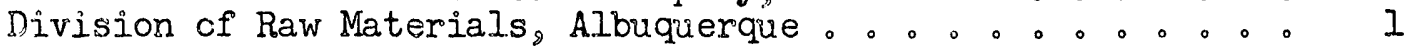

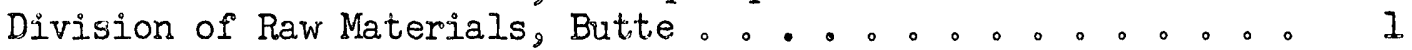
Division of Raw Materials, Denver o. 。 。 . 。 . 。 . . . 1 Division of Raw Materials, Douglas o. . . . . . . . . . . 1 Division of Raw Materials, Grants o. . . . . . . . . . 1 Division of Raw Materials, Hot Springs o. 。 。 。 。 。 。 。 1

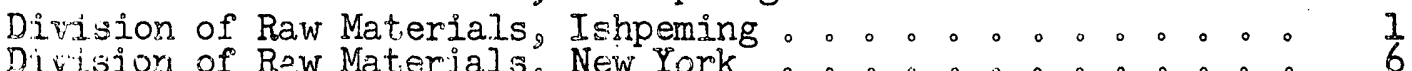
Division of Raw Materials. Phoenix.

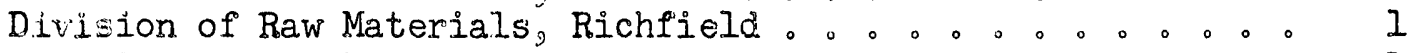
Division of Raw Materials, Salt Lake City - 。 。 。 。 。 1 Division of Raw Materials, Washington o. 。 。 . 。 。 。 3

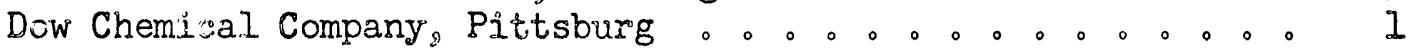
Exploration Division, Grand Junction Operations Office 。 。 - I

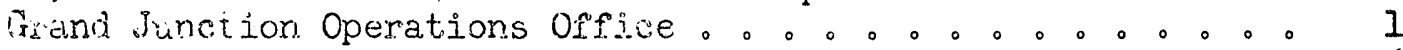

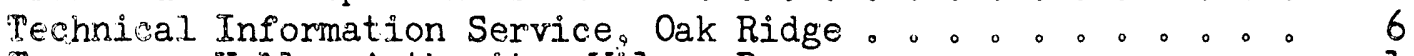
Tennesse Valley Authority, Willson Dam 。。。 。 。 。 。 1 U.S.Geologital Survey:

Alaskan Geology Branch, Washington 。 。 。 。 。 。 。 . I I Fuels Branch, Washington - . . . . . . . . . . . . . . . 1 Geohemistry and Petrology Branch, Washington 。. . 。 。 - 1

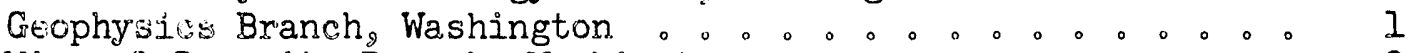

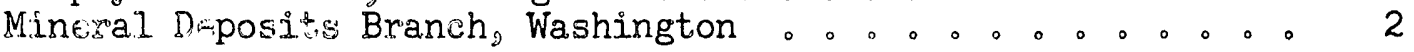

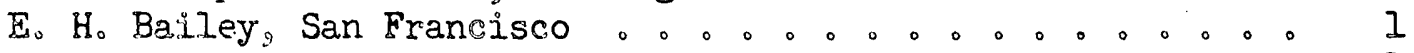

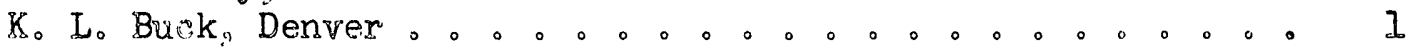

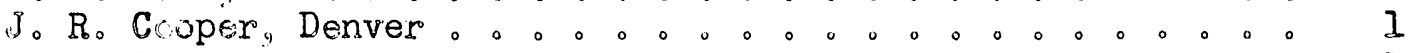

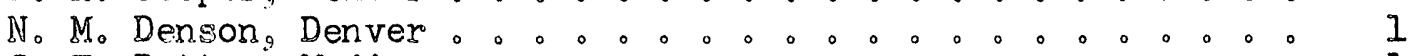

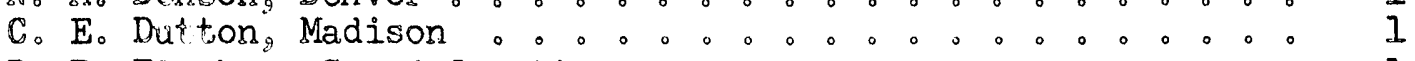

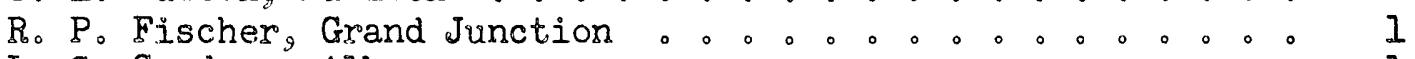

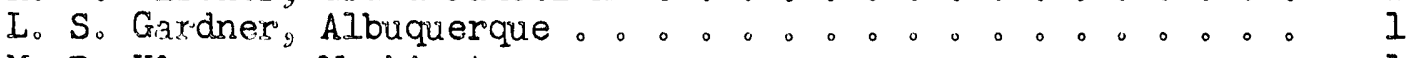

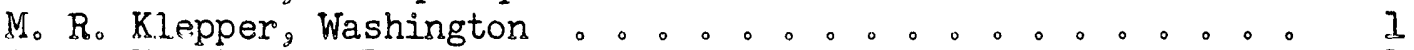

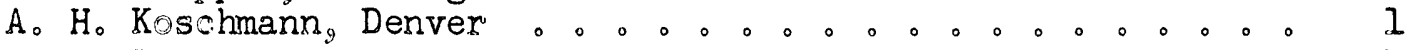

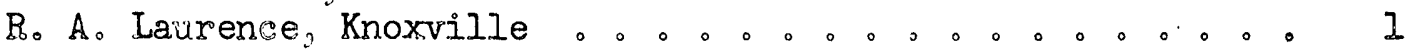

D. M。 Lemmon Washington 。 0.00 .0 .0 .0 .0 .0 .01

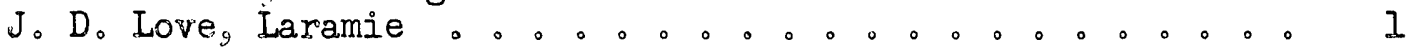

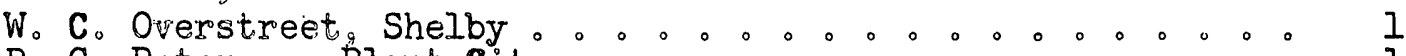

$R_{0} G_{0}$ Peterson, Plant City 。. . . . . . . . . . . . 1

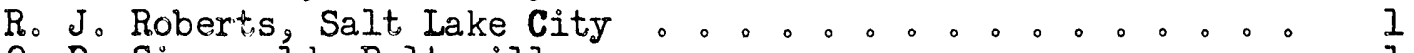

Q. D。 Singewald, Beltsville 0.0 .0 .0 .0 .0 .0 .0 .01

J。F。 Smithy Jrog Denver 。

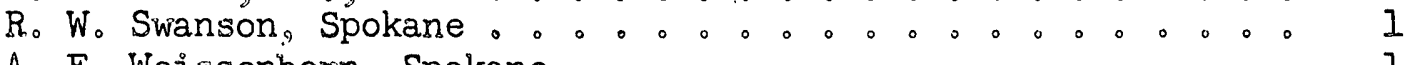

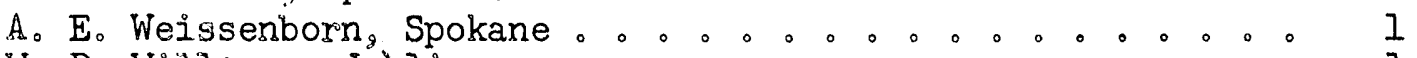

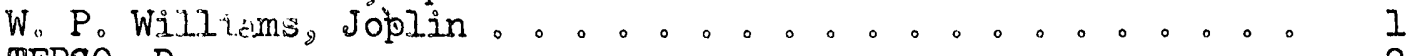

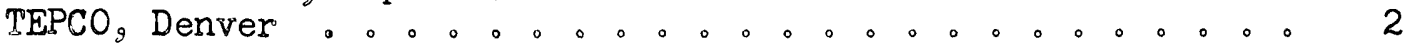

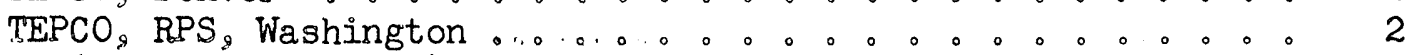

(Ineluding master) 
CONTENTS

Page

Abstract, 0.000 .000 .00000000000000000 (8

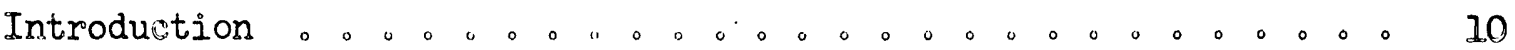

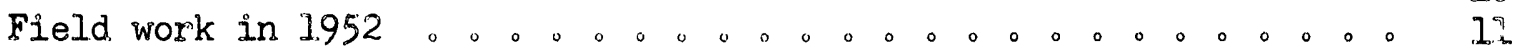

Reconnaissance 00000000000000000000000.11

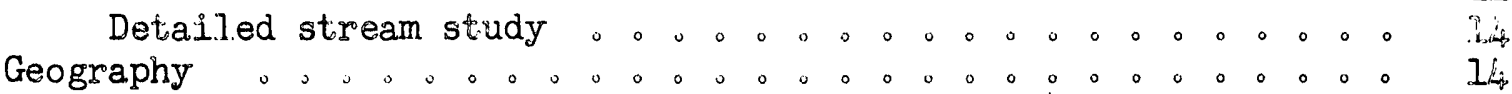

Location, topography, and accessibility o。 $0.0 \circ \circ \circ \circ \circ 14$

Savannah River - Catawba River district 。。 。 。 。 15

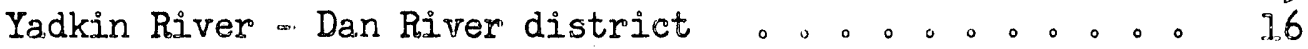

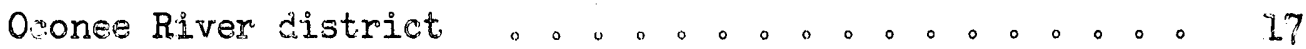

Flirst River district. 0.000 . 0.00 .000 .0 .17

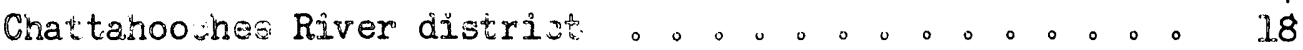

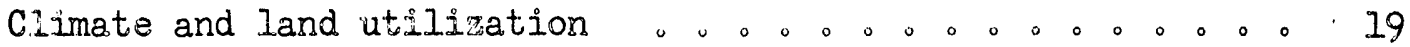

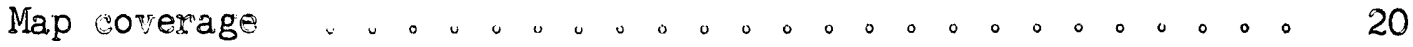

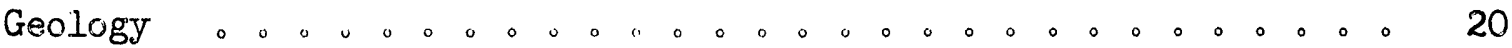

Crystalinine rocks 0.00000000000000000002

Petrography and structure 0.000000000000023

Savannah River . Catawba River district 。. . . 23

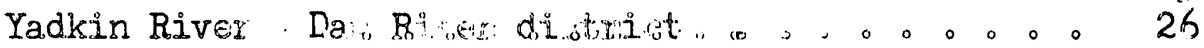

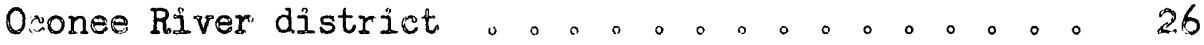

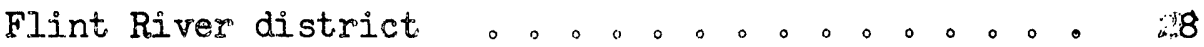

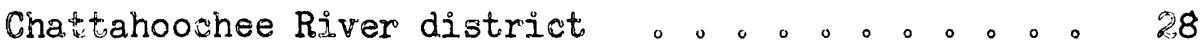

Weathering o. 0. 0. 0.0.0.0.0.0.0.0. 29

Monazite in erystalline rocks o. . . . . . . . . . 32

Crystalline rocks as sources of monazite o.。. 32

Relation to associated minerals in placers 0.0 .57

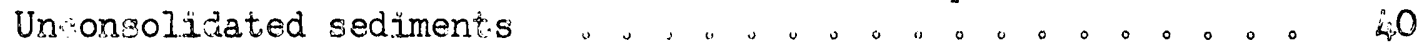

Alluvial sediments,$\ldots ., \ldots$

Thickness and relationships of flood-plain sediments 0.0 .0 .0 .0 .0 .0 .04

Available detritus for coarse sediments . . . . . 44

Age of alluvium $0 . \ldots .0 .0 .0 .0 .04$

Relation of monazite to alluvium o. . . . . . . . . 455

Colluvial sediments and residual deposits . . . . . 49

Colluvial sediments ". . . . . . . . . . . . . 49

Residual deposits 0.00 .0 .0 .0 .0 .0 .0 .51

Relation of monazite to colluvial sediments " " "

Geomorphology

Geomorphic factors o. . . . . . . . . . . 54

Relief 0.00 .00 .000 .00000000054

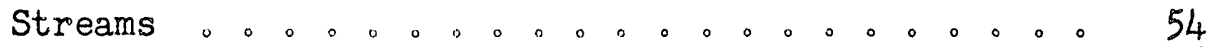

Flood plains o. . . . . . . . . . . . . . . 56

Relation of monazite to geomorphology . . . . . . 57 


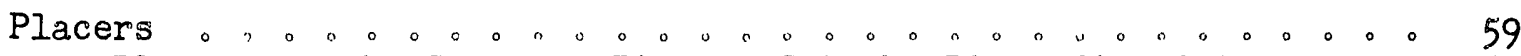

Placers in the Savannah River - Catawba River district 。 。 62

Savannah River drainage , . . . . . . . . . . 62

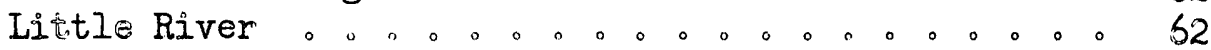

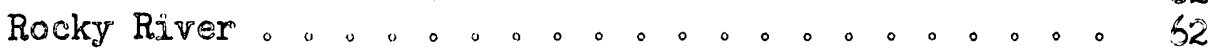

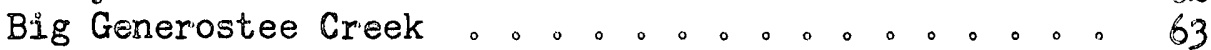

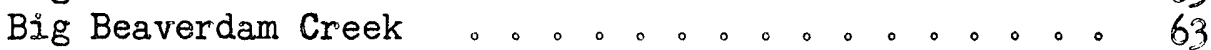

Tributaries to the Seneca River o. . . . . . 65

Saluda River drainage o. 0. 0.00 .0 .0 .0 .0 .64

Saluda River and smaller tributaries ..$\circ \circ \circ .6$ bi

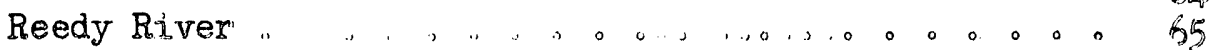

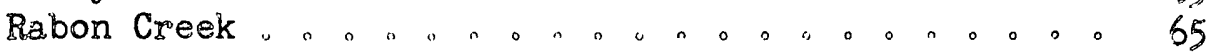

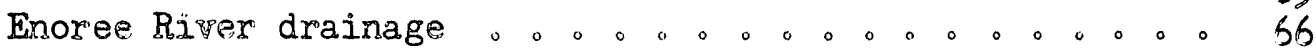

Tygre River drainage o. . . . . . . . . . . . . . . . . 67

South Tygre River o. 0.000 .000 .0000067

North and Middle Tygre Rivers $n$. $0.0 \circ \circ . \circ 67$

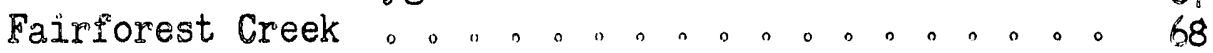

Pacolet River drainage o. . . . . . . . . . . . . 69

Lawsons Fork Creek 。. . . . . . . . . . 69

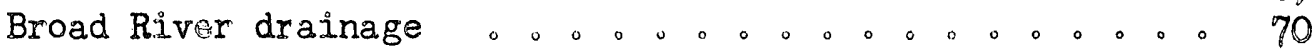

Southern tributaries to the Broad River 。. 。. 72

Northern tributaries to the Broad River o.。.。. 73

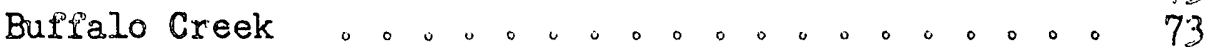

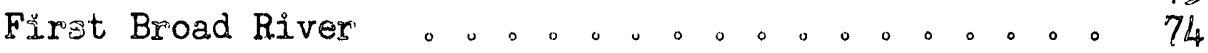

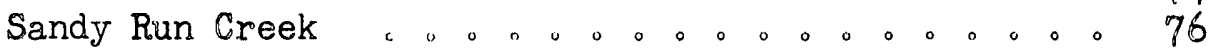

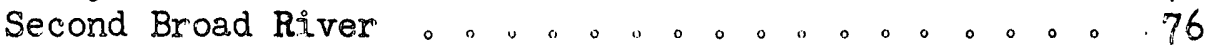

Catawba Raver drainage o o. . . . . . . . . . . . . . 79

Catawba River tributaries o.0.0.0.0.0.

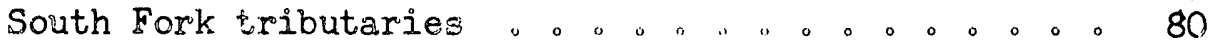

Placers in the other districts o. 0.00 .0 .0 .0 .08 .

Yadkin River - Dan River district o. 。 - 。. . 。 . 81

Oconee River district o. . . . . . . . . . . . $8 \mathrm{M}$

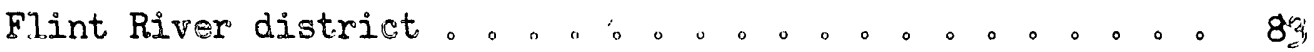

Chattahoochee River district o. . . . . . . . . . . 8

Placers in trunk drainage 0.0 .0 .0 .0 .0 .0 .0 .084

Possible byproducts of placers 0.0 .0 .0 .0 .0 .0 .08

Summary and conclusions o. . . . . . . . . . . . . . . . . 87

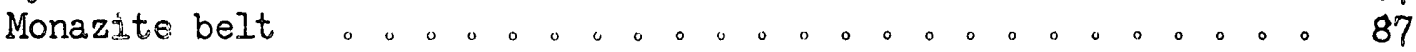

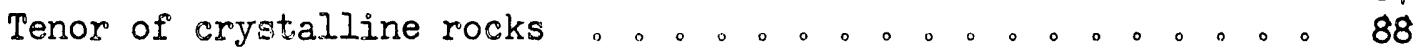

Role of saprolite 0.0 .00 .0 .0 .0 .0 .00 .0 .088

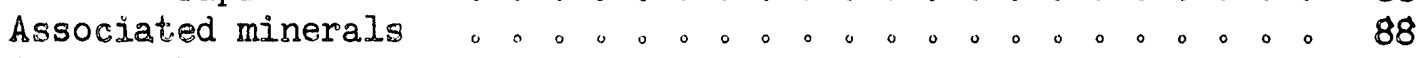

Age of placers 0.00 .00 .0 .0 .0 .00 .0 .0 .0 .0 .089

Sequence of sediments 0.0 .0 .0 .0 .0 .0 .0 .0 .089

Tenor of monazite related to grain size and

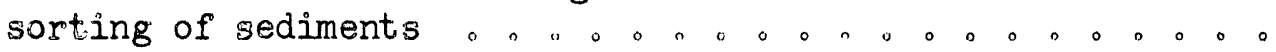


CONTENTS .Continued

Tenor of monazite related to size and position of rlood plainis . . . . . . . . . . . 90

Role of colliuvium and the possibility of eluvial deposits o. . . . . . . . . 。 . 90

Terrace deposits . . . . . . . . . . . . 91

Deposits in trunk drainage .............. 91

Mining in the western belt . . . . . . . . 。 . 9

Recommendations 。. . . . . . . . . . . 。 。 92

Physizal exploration 。 . 。 . . . 。 。 。 。 92

Enoree River … 。 . . . 。 。 。 。 。 92

Sulth Tygrs River 。 。 。 。 。 。 。 。 。 93

Fairfores Creek o. 。 。 。 。 。 。 。 。 93

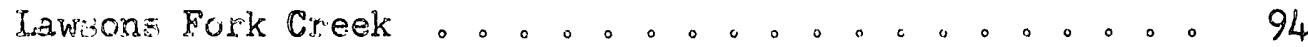

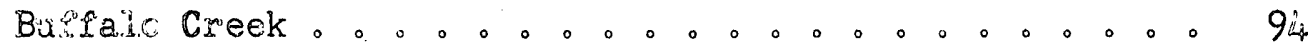

Intermediate sized flood plains . . . . . . . 。 95

Broad Mouth Creek 。 o 。 。 。 。 。 。 。 . 95

Big Bearerdam Creek 。. . . . . . . . . . 96

Durbin and South Duxbin Creeks . . . . . 。 。 95

Pasolet, River 。 。 。 . 。 。 。 。 。 。 。 97

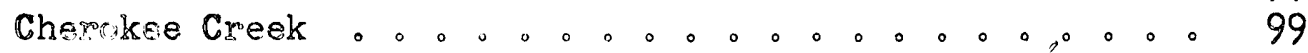

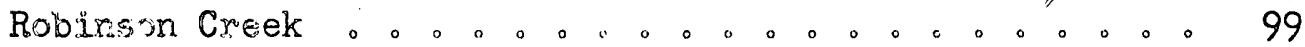

Jun tion of Henry Fork and Jacob Fork 。. . 。 。 100

Henry Fork 。 。 。 。 。 。 。 。 。 。 100

Subordinate atudies o. . . . . . . . . 。 100

Eluvial placers 。. 。 。 。 。 。 。 。 。 101

Study of suitable mining methods o. . 。 . 。 。 101

Stady f trunk drainage . . 。 . 。 . . 。 . 102

Literature ciced o. . . 。 。 。 。 。 。 。 。 。 102

Unpublished reporis o. . . . . . . . . . . . . . 104 


\section{TABLES}

Table 1. Summary of field work in reconnaissance of stream depoin, seasons of 1951,52

2. Frequency disuribution of monazite bearing samples from rocks in the Shelby quadrangle. North Carolina

3. Rank of erystalline rocks as sources of monazite, based on frequency distribution of monazitembearing samples and on amounts of monazite in the sampleso. .

- Rank of eryatiline rooks in the She tby quadrangle a. sources of monazite, based on frequenty distri. bution, amount:a of monazite, and area of outcrop

5. Relation of heavy minerals in placers to souras rouks

6. Physical characteristics of some flood plains in

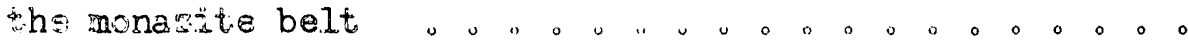

7. Conentrates from source plaeer gravel on tributaries to the Second Broad River east of Cane Creek

8. Convenwate from source placer gravel on tributaxies to the Sesond Broad River west of

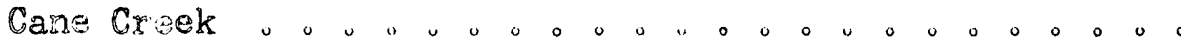


ILLUSTRATIONS

Plate 1. Map showing the five districts investigated for monazite in the western Piedmont of Virginia. North Carolina, South Carolina, Georgia . . . . In envelope

2. Map showing drainage and distribution of samples in the Savannah River - Catawba River district, South Carolina and North Carolina . . . . . . In envelope

3. Map showing drainage and distribution of samples in the Yadkin River - Dan River district, North Carolina

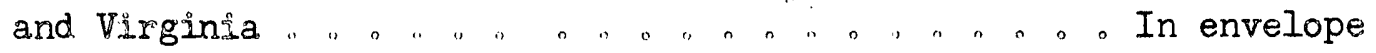

4. Map showing drainage and distribution of samples in the Oconee River district, Georgia . . . .... In envelope

5. Map showing drainage and distribution of samples in the Flint River district, Georgia .

5. Map showing drainage and distribution of samples in the Chatahoo hee River district, Georgia o.。. In envelope

7. Site 7 Big Generostee Creek and Mountain Creek, Anderson County. South Carolina .......... In envelope

8. Site North Rabon Creek and South Rabon Creek? Laurens County. South Carolina . ....... In envelope

9. Site is Downstream from juntion of North Tygre River and Middle Tygre River, Spartanburg Count.y. South Carolina 0.0 .0 .0 .0 .0 In envelope

10. Site 3 junction of Buffalo Creek with Broad River, Cherokee County, South Carolina ......。.In envelope

11. Site 5 Thicketty Creek, Cherokee County, South Carolina . . . . . . : . . . . In envelope

12. Site I South Muddy Creek, MeDowell County,

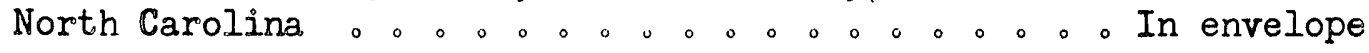

13. Site 2 Siller Creek, Burke County, North Carolina 。In envelope

14. Index map showing sites most favorable for churn drilling in the western Piedmont North Carolina and South Carolina In envelope 
PROGRESS REPORT OF SOUTHEASTERN MONAZITE EXPLORATION, 1952

By $W_{\circ} C_{\circ}$ Overstreet, $P \circ K_{\circ}$ Theobald, $\mathrm{Jr}_{\circ}, \mathrm{A}_{\circ} \mathrm{M}_{\circ}$ White,

$\mathrm{N}$ 。 $\mathrm{P}$ 。 Cuppels, D。W。Caldwell, and J。WoWhitlow

\section{ABSTRACT}

Reconnaissance of placer monazite during the field season of 1952 covered 6,600 square miles drained by streams in the westrin Piedmon: af Virginia, North Carolina, South Carolina, and Georgia. Emphasis during this investigation was placed on the area between the Savannah River, at the border of South Carolina and Georgia, and the Catawba River in North Carolina because it contains most of the placers formerly mined for monazite. Four other areas along the strike of the monazite bearing crysta.line rocks were also studied。They center around Mt, Airy, $N_{\circ} C_{\text {oy }}$ Athens; $\mathrm{Ga}_{\circ}, \mathrm{Griffin}, \mathrm{Ga}_{\circ}$, and LaGrange, $\mathrm{Ga}$.

In the Savannah River "Catawba River district, studies indicate that ewenthe highest grade stream deposits of more than 10 million cubic yards of alluvium contain less than I pound of monazite per cubic yard. The average grade of the better deposits is about 0.5 pound of monazite per cubic jardo. Only trace amounts of niobium, tantalum, and tin have been detected in the placers. Tungsten is absent. Locally gold adds a few cents per cubic yard to the value of placer ground. The best deposits range in size from 1 to 5 million cubic yards and contain 1 to 2 pounds of monazite to the cubis yard. Hundreds of placers smaller than 1 million 
cubic yards exceed 2 pounds of monazite to the cubic yard and locally attain an average of 10 pounds.

Monazite deposits around Athens, Ga, are similar to the smaller deposits in the central part of the Savannah River - Catawba River district. A few small, very low-grade monazite placers were found near Mt. Airy, N。C。 Griffin, $\mathrm{Ga}_{\circ}$, and LaGrange, $\mathrm{Ga}_{\circ}$, but they are of no economic value.

The larger the flood plain and the farther it lies from the source of the stream, the lower is the monazite content of the sediment. Monazite cannot be profitably mined from the crystalline rocks in the five areas。

The alluvial placers are in stream sediments of post-Wisconsin age。 Some prewisconsin terrace gravel of small areal extent is exposed, but it contains only a small amount of monazite. Prewisconsin to early post. Wisconsin colluvial sediments locally contain 2 pounds of monazite to the cubie yard。

Mode of presentation of reports covering field work during the seasons of 1951. 52 is given. No further reconnaissance will be undertaken in the western monazite belt. 


\section{INTRODUCTION}

Monazite placers in streams of the western part of the Piedmont in Virginia, North Carolina, South Carolina, and Georgia have been studied. The object was to deseribe local monazite deposits, to determine geologie controls of monazite placers in the southeastern Piedmont, and to evaluate placer potentialities of the area。

Monazite has been the chief ore of rare earths and thorium. Most monazite produced in the United States from $188 \%$ until 1917, when imported ore supplanted domestic sources, came from small placers in western North and South Carolina. Prior to 1945 reperts on monazite in the southeast (Gench, 1891, po 77-78; Pratt, 1904, po1163-1170; Pratt, 1916, po26-68\% Slcan, 1908, po 129-142, Sterret, 190\%, po 1195-1209) provided only general discussions of geology, mineralogy, and reserves of these deposits. Investi-. gations begun by the U.S.Geological Survey in 1945 and sontinuing into 1953 are giving new data on distribution of monazite bearing crystalline rooks and monazite placers in the southeast (Mertie, 1.953: Overstreet, and Theoba.ld。 1952, p。12-.17)。

This progress report reviews briefly the recent reconnaissance studies of monazite placers in the southeastern Piedmont, shows current status of the work $\left(F \in b_{0}, 1953\right)$, summarizes tentative views of the origin and occurrences of the placers, outlines subordinate problems, and presents plans for completion of the investigation. This work was done on behalf of the Division of Raw Materials of the U.S.Atomic Energy Commission. 


\section{OFFICIAL USE ONLY}

FIELD WORK IN 1952

The second field season for reconnaissance of stream deposits in the monazite belt commenced April 2, 1952, and closed December 5, 1952。 Dur ing that time the area proposed for reconnaissance (Overstreet and Theobald, 1952, p。29-32) was completed. Detailed study of Knob Creek, Cleveland County, N。Co, was begun June 18, 1952, and was halted in October 27, 1952.

\section{Reconnaissance}

Reconnaissance of streams consisted of: (1) stereoscopic interpre-m tations of $1: 20,000$ scale aerial photographs to outline flood plains, (2) field checks of stereoscopic interpretations, (3) collecting heavyco mineral concentrates from measured grab samples of the different types of alluvial sediments in the drainage of each stream, (4) measuring exposed sections of sediments, and (5) auger drilling to determine thickness and sequence of sediments. A statistical summary of work in the field seasons of $1951 \therefore 52$ is given in table 1 。 
12

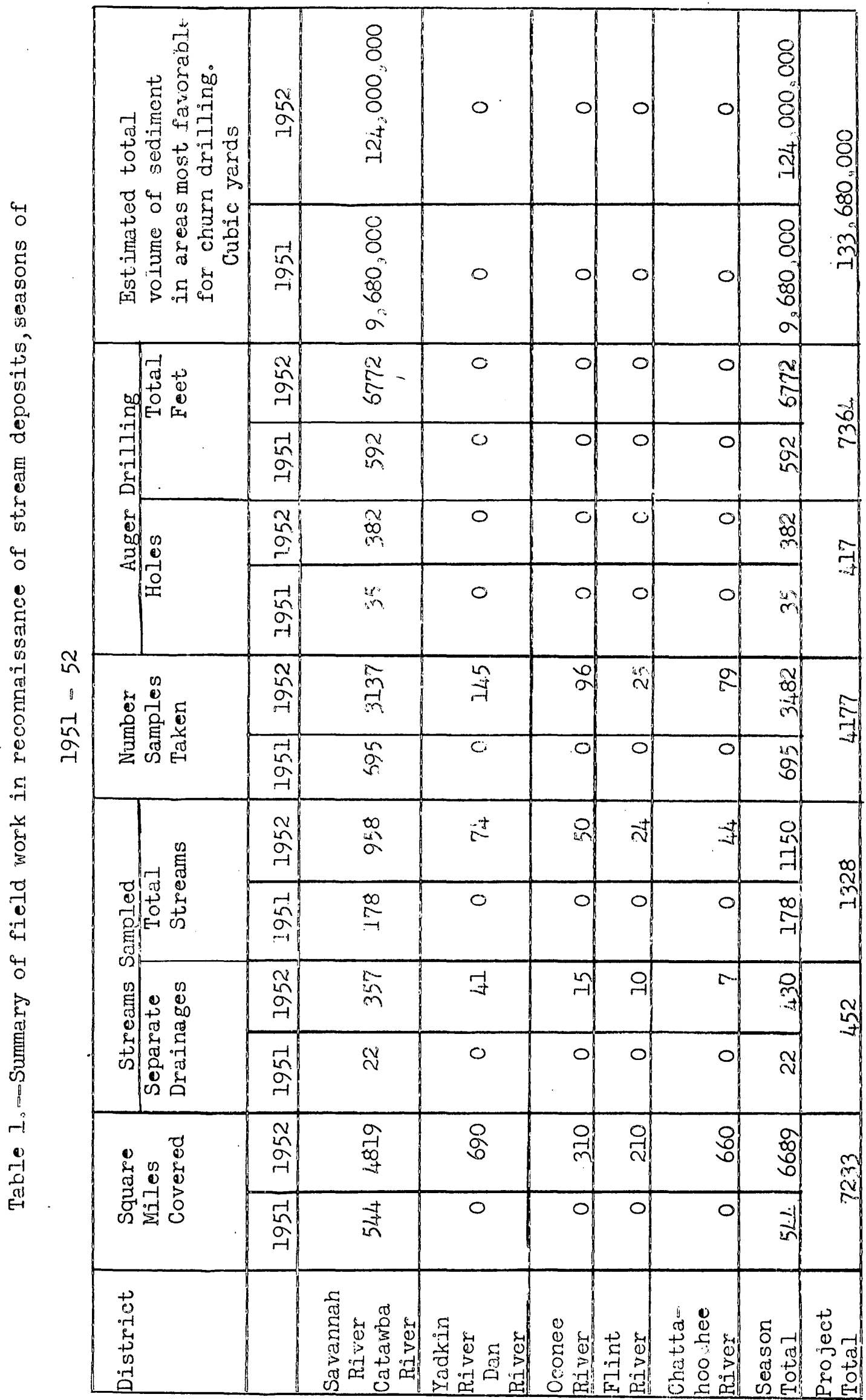


Stereoscopic interpretation of $1: 20,000$ scale aerial photographs showed location and size of flood plains along the separate streams and guided reconnaissance. Margins of flood plains as drawn on the aerial photographs enclosed stream deposits, alluvial fans, and terrace deposits。 Spot checks of the interpretation were made at average intervals of one mile along each stream。

Grab samples, consisting of measured volumes of separate types of stream sediments, were taken at average intervals of I mile along each stream studied. The samples were screened and panned to concentrate mona. zite and associated heavy minerals. Grain counts on the concentrates are being made by personnel in the Trace Elements Laboratory of the U。 S。 Geo, logical Survey in Washington. From these grain counts weights of monazite and associated heavy minerals in each sample are calculated. Concentrates from each grab sample, after corrections for loss in panning and swell in volume of sampled sediment, give estimated tenor of the indiwidual type of sediment at the place in the stream where the sample was collected. From these samples and the estimated thicknesses of the separate sediments in the different parts of the stream, inferred reserves of the separate streams will be calculated. Appraisal of each district as a source for monazite can be made from data obtained on all streams in the district. The most favorable areas for exploration can be selected by comparisons among the streams。

Exposed sections of stream sediments were measured at the localities where samples were taken. Auger holes were drilled in flood plains to 


\section{OEEXCIAL USE ONESY}

14

supplement measured exposures. Observations made at about 3,000 exposures and in 417 auger holes provide data from which approximate thickness and distribution of the different types of sediments can be plotted.

\section{Detailed stream study}

The detailed study of Knob Creek, Cleveland County, N。C, was undero taken to gain knowledge of processes of monazite placer formation in areas widely underlain by saprolite. A plan for the study was outlined in an earlier report (Overstreet and Theobald, 1952, p。30) and has been followed in the investigation undertaken by J.W. Whitlow in June 1952 .

\section{GEOGRAPHY}

\section{Location, topography, and accessibility}

Five districts (plate 1) were covered by reconnaissance during the field season of 1952。 Division into districts allowed wide geographic sampling: no inference is intended that monazite is restricted in its distribution along the strike to these districts. Northwest and southeast boundaries of the districts mark the outer margins of monazite bearing crystalline rocks。

These five districts have been named after trunk streams to which local drainage is tributary。 They are called: (I) the Savannah River Catawba River district, (2) the Yadkin River - Dan River district,
(3) the Oconee River district, (4) the Flint River district, and

(5) the Chattahoochee River district. 


\section{OFFICIAL USE ONLY}

Savannah River - Catawba River district

The Savannah River - Catawba River district (plate 2) extends northeastward from the Savannah River at the border between Georgia and South Carolina to the Catawba River in west central North Carolina. All or parts of the following counties are in the district: Greenwood, Abbeville, Anderson, Oconee, Pickens, Greenville, Laurens, Spartanburg, and Cherokee Counties in South Carolina and Polk, Rutherford, Cleveland, Gaston, Lincoln, Catawba, Burke, and McDowell Counties in North Carolina.

The relief of the west margin of the district increases northeastward as the margin passes east of the Blue Ridge in Greenville County ${ }_{9} \mathrm{~S}_{0} \mathrm{C}_{0} 9$ and into the South Mountains in Polk, Rutherford, and McDowell Counties, N。C. Relief of the east margin of the district also increases northeastward。 Relief decreases across the district from the west margin to the east maro gin. Gently rolling hills are typical of all parts of the district except the rugged areas in the South Mountains.

Four major streams flow southeastward across the district. From southwest to northeast they are the Savannah, Saluda, Broad, and Catawba Rivers. All drainage in the district is tributary to these streams within the district or downstream from its southeast margin. All streams ultimate. ly flow into the Atlantic Ocean。

Principal towns in the district include Morganton, Hickory, Lincolnton, Rutherfordton, and Shelby in North Carolina, and Gaffney, Spartanburg, Greenville, Laurens, and Anderson in South Carolina. Population is heavy throughout the district, but it is less dense in the western than in the 
eastern part A close net of federal and state highways and state secondary roads gives ready access to all parts of the district. All county seats are served by railroads. Electric distribution lines reach most farms in the area.

$$
\text { Yadkin River - Dan River district }
$$

The Yadkin River - Dan River district (plate 3) includes parts of Sursy and Stokes Counties, $N_{0} C_{0}$ and Patrick Count,y, Va。 It centers about Mt. Airy, $N$ 。 Co, a town of 6,300 population. The district extends north ward to the Blue Ridge, westward to the Little Fisher and Fisher Rivers, southward to the Yadkin River, and eastward to the Dan River。 Isolated quartzite ridges stand above the rolling hills of the district: reiler increases toward the north and west as the Blue Ridge is approached。

The Yadkin River flows eastward to form the south boundary of Surry County, thence it flows southward to a point near the center of the state where the name is changed to the Pee Dee River. The Pee Dee River empties into the Atlantic Ocean on the coast of South Carolina. The Dan River heads in Patrick County and flows southeastward into North Carolina. It is tributiary to the Roanoke River, which enters Albemarle Sound on the coast of North Carolina.

The district has a close net of paved and unpaved roads, is served by a railroad, and has electric power. 
Oronee River district

The Oconee River district (plate 4) includes drainage to the Middle Oconee River in Oconee, Barrow, Clarke, and Jackson Counties, $\mathrm{Ga}_{2}$, and to the Oconee River in Oglethorpe County, $\mathrm{Ga}_{\circ}$ The Oconee River, which heads north of the district, flows southward to its confluence with the Ocmulgee River on the Coastal Plain. The two streams combine to form the Altamaha River which discharges into the Atlantic Ocean.

Relief is low, The greatest relief, on the order of 100 feet, is in the youthful valleys of the Oconee and Middle Oconee Rivers downstream from their headwaters. Divides are characterized by broad, gently rolling surfaces. The larger flood plains are near the divides along the head.. waters of the tributary streams。

The largest community in the district ia winder, which has 4,000 population $_{g}$ Athens, with 18,000 population, $_{9}$ is in Clarke County east of the district. A good pattern of paved and unpaved roads give access to the area. Railroad sidings and terminals are maintained at towns in the district. Electric power is available.

\section{Flint River district}

The Flint River district (plate 5) includes parts of Spalding and Pike Counties, $\mathrm{Ga}$ 。 Headwaters of the Flint River are about 20 miles north of the north margin of the district. The Flint River flows southward and southwestward to join the Chattahoochee River at the Florida state line. From this confluence to the Gulf of Mexico the stream is called 
the Appalachicola River. Gently rolling hills with low relief and broad interstream areas are characteristic。

Griffin, the largest city in the district, has a population of 14,000 。 Rural areas are sparsely settled. Although few roads have been paved, there is a good net of unpared roads. One railroad passes through Pike and Spalding Counties. The district is poorly covered by electric diso tribution lines。

\section{Chattahoochee River district}

The Chattahoochee River district (plate 6) comprises parts of Troup, Harris, and Meriwether Counties, $\mathrm{Ga}$ 。 This district is about equidistant from the headwaters of the Chattahoochee River in the Blue Ridge and the mouth of the Appalachicola River (see above) on the Gulf of Mexico.

Troup County and all but a small part of southern Meriwether County are areas of low relief. Pine Mountain, a long, narrow ridge, trends northeastward through Harris County into southern Meriwether County。 The mountain rises 600 feet above the general Piedmont surface to a maximum altitude of 1,400 feet. Streams north and south of Pine Mountain are sub. sequent to the structure of the mountain: the larger flood plains are north of Pine Mountain.

LaGrange is the largest city in the district. It has a population of 22,000 。 In most of rural Troup County the density of population is uniform but moderate, but those parts of Harris and Meriwether Counties inside the district are sparsely settled. The good network of paved and 
unpaved roads in Troup County, contrasted to that in Harris and Meriwether Counties, reflects its greater density of population. Railroads serve the district. Most of the district is reached by electric distribution lines.

\section{Climate and land utilization}

Annual average temperature in the five districts ranges from $56^{\circ} \mathrm{F}$. at Mt。Airy, $\mathrm{N}_{0} \mathrm{C}_{\circ}$, to $63^{\circ} \mathrm{F}$. at LaGrange, Ga. Annual average precipitation ranges from 46 inches to 60 inches over the districts, but it does not closely parallel differences in latitude. Summers are normally hot and humlig winters are damp。

Farms comprise 38 to 89 percent of the land area of the separate counties in the five districts (Anon, 1951). Not all the acreage in tarms is improved land.

Mountainous land along the northwest margin of the Savannah River w Catawba River district is the least heavily farmed section. Eastward arross the district large areas are planted to cotton grain, and peaches. In resent years many acres have been taken out of cultivation to serve as pasture. Bottomland.along streams is mostily wasteland and pasture ${ }_{9}$ but, some is cultivated. The wasteland is usually swampy and covered with heavy vegetation.

In the Yadkin River - Dan River district the less mountainous parts are extensively cleared and farmed for tobacco. Some bottomland is cul-.. tivated or used for pasture.

Land in the Oconee River district is poor and is not as widely culo tivated as the other districts. The major erop is cotton: surreniy mulk 
of the land is being converted to pasture. Bottomlands support a luxuro lant growth of small trees and underbrush.

Much of the Flint River district is uncultivated. Bottomland, which is commonly swampy, is little farmed.

The Chattahoochee River district is similar to the Flint River district in that bottomlands are swampy and uncultivated. In the northern parts of Troup and Meriwether Counties large areas are uncultivated.

\section{Map coverage}

Only scattered topographic coverage is available for the five dis. tricts. About two thirds of the topographic maps date from the early $1900^{\circ} \mathrm{s}$

Uniform planimetric coverage of the five districts is provided by county road maps issued by the highway departments of the separate states. These maps show drainage and roads at a scale of 1 mile to the inch.

Aerial photographs at $1: 20,000$ scale made for the $U_{0}$ S。 Department of Agriculture cover all five districts. Most of these photographs are from the Production and Marketing Administration. A part of the drainage tributary to the Catawba River in North Carolina is covered by aerial photographs from the Soil Conservation Service。

\section{GEOLOGY}

Reconnaissance of monazite placers in the western Piedmont of the southeastern states was guided by the concept of a source for monazite restricted to a belt of monazite bearing crystalline rocks. This belt 
had been defined and discussed by Mertie (1951, p。16-19)。 He showed an area 10 to 35 miles wide that extends from Alabama to Virginia east of the Blue Ridge. Outliers were indicated, the largest of which is near Dahlonega, $\mathrm{Ga}$ 。 In this belt some rocks contain monazite and others do not. Monazite most commonly occurs as an accessory mineral, in some bodies of granitic gneiss, granite, and pegmatite: however, not all granitic rocks in the belt are monazite-bearing。 Less commonly monazite is an accessory mineral in some paragneiss and schist。

Mertie refers to this area as the western monazite belt to distinguish it from a similar but smaller area near the east edge of the Piedmont in Virginia and North Carolina. All placers from which monazite was mined during the history of the industry are in the western monazite belt. For that reason this investigation has been confined to the western belt.

Five districts along the belt were selected for study to give a sampling of geological environment throughout the belt. Greatest atten tion was given to the Savannah River - Catawba River district because it contains most of the deposits formerly mined. By studying all five dis tricts, differences in crystalline rocks, unconsolidated sediments, geomorphology, and placers over the whole area became more apparent. A brief review of the crystalline rocks, unconsolidated sediments, and gevmorphology in the five districts is given below. 


\section{Crystalline rocks}

The Piedmont province of the southeastern Atlantic states is not well known geologically。 State geologic maps have been published of Virginia (Stose, 1928) and Georgia (Stose, 19339), and a generalized map of the geology of North Carolina was released in 1937. Other publications concerning the province include reports on mining districts and studies of regional mineral resources, a few county geologic maps, papers on special problems, and several geologic quadrangle maps by the U。 S。 Geological Survey. Little more than a hint at the complexity of this metamorphic ferrane can be gathered from these sources because coverage is inadequate and incomplete, broadly inclusive units were commonly used for mapping, correlations were largely petrographic, and rank of metamorphism was used to establish selative ages of the units mapped.

Fundamental knowledge of the crystalline rocks and regional structure in most of the monazite belt is nearly as lacking as it is elsewhere in the Piedmont. The most complete data are in four quadrangles near Shelby, No $C_{0}$, in the northeastern part of the Savannah River - Catawba River dis trict. The geology of these four quadrangles has been mapped by Yates and others (1953), Keith and Sterrett (1931, po 1-13), and Sterret. (1912). Ge,1.2. sy of parts of the district in North Carolina is generalized on: maps drawn by LeGrand and Mundorff (1952, figs。11, 13, 15, 19, and 21) and Hunter and White (1946, pl。1)。Geological reports in the Yadkin River o Dan River district are restricted to discussions of the granite quarries at Mt. Airy, N。Cog (Watson, 1910, pl。13, p。148-151) and water-supply papers 
(Etheridge and Riley, 1948, fig。2: Mundorff, 1948, pl。1)。 In the Oconee River district Parizek J recently began mapping Clark County, Ga。 Oîher

d Parizek, E。 J。g 1952, personal communication。

than the state map of Georgia no geologic map covers the Flint River district. Short descriptions of the granitic rocks in Pike and Spalding Counties, Ga。, are given by Watson (1902, $\mathrm{p}_{0}$ 96-101)。 A small area in the southeastern part of the Chat, tahoochee River district is included in mapping done by Hewett and Crickmay (1937, $\mathrm{pl}$ 。1)。

\section{Petrography and structure}

Savannah River - Catawba River district,...- The Savannah River - Catawba River district is underlain by paragneisses and schists into which granitic and mafic rocks have been introduced. A sequence of metamorphosed sediments called the Carolina gneiss (Keith and Sterret, 1931, p。3) and cono ventionally dated as pre-Cambrian has the widest distribution in the district. The Carolina gneiss consists of interlayered biotite gneiss, biotite schist, and sillimanite schist, with rare layers of hornblende gneiss and marble. Much less widely distributed is the unit called the Roan gneiss (Keith and Sterrett, 1931, p, 3-4), which is chiefly horn blende gneiss, hornblende schist, and schistose diorite. It was inter.preted by Keith and Sterrett as intrusive into the Carolina gneiss and as pre-Cambrian in age. Other intrusive mafic rocks include pre-Cambrian gabbro and pyroxenite, and diabase of Triassic age. Bodies of granitic 


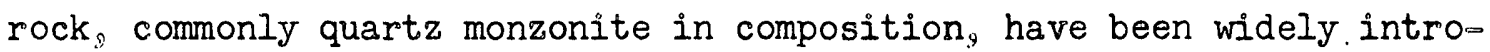
duced as thick sills in the Carolina and Roan gneiss. Ages of the granite ic rowks are not well known some have been assigned questionably to pres Carboniferous and Carboniferous time (Griffitts and Overstreet, 1952, p. 788)。 Dikes and sills of pegmatite are common。

Objections have been raised by Kesler (1944, p.779-780) and Yates et $a l_{\circ},(1953)$ to earlier interpretations of ages and relationships of the Carolina gneiss and Roan gneiss in this area. Grade of metamorphism has been used as evidence for age, but it has been shown that schists of . the Carolina type are interlayered with other supposedly younger lower $_{\mathrm{s}}$ rank metamorphie rocks. Some hornblendembearing rocks of typical Roan aspect are metamorphosed sediments, not metamorphosed mafic igneous rocks. Until detailed mapping in critical areas has resolved these problems, the terms Carolina gneiss and Roan gneiss should connote only lithologịc characteristics: no correlative implication should be conveyed. In that sense the terms are used in this reporto

Biotite schist, biotite gneiss, and sillimanite schist of the Carow lina gneiss underlie most of the district. They extend across the full width of the monazite belt. In Polk, Rutherford, and McDowell Counties, N. Con hornblende gneiss, gabbro, and diorite are common along the west edge of the belt. In Lincoln and Catawba Counties, $\mathrm{N}_{0} \mathrm{C}_{0}$, hornblende gneiss appears at the east margin of the belt. Southwestward from Lincoln County into Cherokee County, $S_{0} C_{0}$, the east edge of the belt is marked by monazite-free granitic rock in biotite schist and sillimanite schist. In southern Cherokee County and northern Spartanburg County, S。Cog 
the southeast edge of the monazite belt abuts monazite-free sericite schist, biotite schist, and granitic rocks. Farther southwest the margin of the belt in Spartanburg, Laurens, Greenwood, and Abbeville Counties,

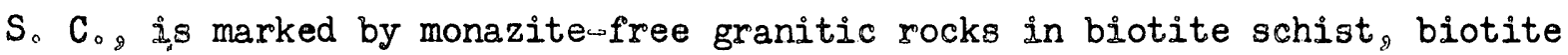
gneiss, and hornblende gneiss. The west boundary resembles the southern part of the southeast margin of the belt.

Granitic rocks are interlayered with the metamorphosed sedimentary rocks of the district. The inter layered granitic bodies range in size from little stringers of pegmatite 0.1 inch thick and 2 or 3 feet in length to sills of gneissic quartzimonzonite 3,000 to 4,000 feet thick and 10 miles long. The greatest introduction of granitic material was into sillimanite schist and biotite achiet, both of which locally become injection gneiss: Biotite gneiss and hornblende gneiss appear to have' been more competent than the schists and have been less invaded by gra: nitide rows。

No Indisputable relic bedding has been recognized in the part of the Savannah River - Catawba River district covered by geologic mapping。 The principal planar structure is foliation, which trends generally north $\Rightarrow$ eastward. Locally this trend varies toward the north and northwest. Dips range from horizontal to vertical with most between $15^{\circ} \mathrm{SE}_{\circ}$ and $60^{\circ} \mathrm{SE}_{,}$, but westerly dips are not uncommon. Folding ranges in magnitude from small structures visible in one outerop, such as chevron, drag, and simple open folds, to great structures only evident on several quadrangle maps, such as large isoclinal folds. Overthrust faulting probably accompan.ied tight folding, but thrust planes are rarely seen in the field. Thrusts 
may be inferred from the outlines of some units on geologic maps. High angle normal and reverse faults of small displacement are seen in outcrops. Yadkin River $\infty$ Dan River district. $\rightarrow$ The Yadkin River o Dan River district is underlain by lower -rank metamorphic rocks than is the Savannah River $\cdots$ Catawba River district. Fine grained biotite gneiss and biotite schist are the most.:common. rocks in the area. Amphibole schists and gneisses are present Iocally。 Pyroxenite associated with hornblende gneiss occuss in the southeastern part of the district. Quartzite in which bed ding is preserved is abundant in the southern and southwestern parts of the district. Tale ohist and corlorite sohist crop out in the same area. Ser'icite phyllite, garnetiferous muscovite schist, and biotite schist are the most abundant rocks in the northern part of the district. Staurolite is common in much of the muscovite sihist. Localiy masses of hornblende schist and mica sehist are richly garnetiferous。

Massive and gneissic granite crops out at many places, but pegmatite is rare. Injection gneiss and migmatitic rocks, common in the Savannah River Catawba River and Oconee River districts, were not seen in the Yadkin River .. Dan River district。

Otonee River district. The Oconee River district is underlain by highly metamorphosed sedimentary rocks into which granitic rocks were introduced to produce a complex terran'; of injection gneiss and migmatite. The geologic map of Georgia (Stose, 1939) shows that the Oconee River district is underlain largely by biotite gneiss and biotite schist of the Carolina series (the convention used for a lithology similar to that called 


\section{OFFICIAL USE ONLY}

27

Carolina gneiss in North and South Carolina)。 A small body of granite is shown intrusive into the Carolina series in Clarke County west of Athens, and.a larger body of the "same granite" marks the northwestern boundary of the district in Barrow and Jackson Counties. A different type of granite is shown at the southeast margin of the district in Oglethorpe County。

In recent work Parizek I has found that the granite near Athens

d Parizek, E。 Jo, 1952, oral communication.

is more extensive than the state map indicates. The body of granite with included gneiss underlies most of Clarke County and widens toward. the south. For mapping Parizek has subdivided the undifferentiated biotite gneiss and schist of the Carolina series into three units: bio.tite schist, biotite gneiss, and sillimanite schist. Small diabase dikes and some hornblende gneiss were found.

The granite at Athens contains monazite. The granite in Barrow and Jackson Counties on the northwest boundary of the district and the granite in Oglethorpe County at the southeast margin of the district contain no monazite. Heavy mineral suites from these two granites dif fered markedly from each other and from monazite bearing suites characo teristic of the granite at Athens. In Barrow and Jackson Counties gneissic phases of the granite give abundant magnetite with some zircon and no monazite. massive phases of the rock give virtually monomineralic 
concentrates of zircon. The granite in Oglethorpe County gives concen. trates consisting almost entirely of magnetite with scant zircon and no monazite, Each of these heary-mineral assemblages is very large in contrast to the small suites gotten from the monazite-bearing granite near Athens。

Flint River district. $\omega$ The Flint River district is underlain by biotite granite intrusive into biotite gneiss and biotite schist of the Carolina series (Stose, 1939)。Poorly developed foliation in the granite trends $\mathbb{N}_{2} 20^{\circ} \mathrm{E}$, to $\mathrm{N}, 10^{\circ} \mathrm{W}$ and dips gently eastward Observations at a few localities show that the Carolina series strikes N。20 $400 \mathrm{E}$ 。 with a gentle southeasterly dip. No contacts between the granite and. the Carolina series were seen: structural relations in the district are unknown.

Chattahoochee River district - Rock $s$ underlying the Chattahoochee River distriet can be divided into two groups: (1) the granites, gnoisses, and schists north of Pine Mountain, and (2) metasedimentary rocks of the Pine Mountain series (Stose, 1939). The Towaliga fault separates the two groups (Hewett and Crickmay, 1937, p. 31)。

Granite gneiss, biotite gneiss; biotite schist, and hornblendebearing biotite gneiss in the northern part of the district are fineito coarse..grained rocks. Their well developed foliation trends from N. $75^{\circ} \mathrm{E}$. to $\mathrm{N}_{0} 35^{\circ} \mathrm{W}$. Biotite granite intrudes the gneisses and schists. Commonly the granite is coarserwgrained than the gneisses. Roughly paral le flakes of biotite mark a crude foliation in the granite. Locally both granite and gneisses are intruded by pegmatite. Dikes of pegmatite wut across the structure of the granite and gneiss, but more commonly 


\section{OFFICIAL USE ONLY}

29

pegmatite bodies are thin lenticular masses parallel to the foliation of enclosing rocks.

Metamorphosed sedimentary rocks of the Pine Mountain series are restricted to a narrow belt that trends northeastward across Harris County into southern Meriwether and Pike Counties. From the oldest to the youngest unit the series, as described by Hewett and Crickmay (1937, p. 27-29), comprises the Sparks schist, the Hollis quartzite, and the Manchester schist. The Sparks schist is interlayered muscovitembiotite schist, biotite gneiss, and thin beds of quartzite into all of which granitic material has been injected. The Hoilis quartzite is thin-s to thick-bedded quartzite in which some sedimentary structure is preserved. The Manchester schist is a kyanitic muscovite schist。

Cutting across all other rocks in the district are Triassic diabase dikes that trend a few degrees west of northo

Because rocks north of the Towaliga fault are more highly metamor phosed than rocks south of the fault, Hewett regards the northern group as the older. All rocks in the district except the diabase dikes are called pre. Cambrian。

\section{Weathering}

Crystalline rocks in the monazite belt have undergone profound chemical weathering. This weathering has attacked rocks of all ages and types from the older gneisses and schists, through premCarboniferous and Carboniferous granitic rocks, to Triassic diabase dikes which are the young $\rightarrow$ est crystalline rocks in the area. Chemical. weathering of fresh rocks, particularly of gneisses and granites, produces large amounts of impure clay. This 


\section{OFFICIAL USE ONLY}

30

results from the alteration of plagioclase and, to a lesser degree, of potash feldspar. The presence of etched quartz indicates local condico tions favoring the solution of silica. Accessory minerals such as magnetite, ilmenite, rutile, zircon, and monazite are notably resistant to weathering。

Erosional processes in the southeast have not kept pace with chemical weathering。 Consequently extensive areas of saprolite are preserved。Becker (1895, po.289-290) proposed "the term saprolite as a general name for thoroughly decomposed, ${ }_{9}$ earthy, but untransported rock." Many saprolites preserve the original texture and structure of the rock well enough to permit identification of the rock and to allow measurement of planar and linear features. No disparity is perceptible in structures mapped across alternate areas of saprolite and hard rock。

The typical color of undisturbed saprolite of all rocks near the surface of the ground is dark red. At depth the original colors of leucocratic rocks are commonly well preserved in saprolite, but melano. cratic rocks change in color when converted to saprolite. Thus biotite rich schists and gneisses change from dark gray fresh rock to bronzy or greenish-yellow saprolite, and dark green or black hornblende rich rocks change to yellow-brown or mustard-colored saprolite.

The average depth of saprolite over the monazite belt is not known. The maximum reported depth is 180 feet logged in a water well near Cherryville in Gaston County, N。Co, a few miles east of the Savannah River - Catawba River district. In many highway cuts, railroad cuts, and erosion gullies 25 to 50 feet of saprolite is exposed without baring 
hard rock. Pardee and Park (1948, p. 24) report that in most gold mines in the southeast saprolite is less than 75 feet deep, but at a very few properties it extends 150 feet or more below the surface of the ground. Layers of unweathered rock may be completely surrounded by saprolite. A gradual lessening of the effects of weathering through a zone of several feet is reported (Pardee and Park, 1948, p。24.27), but the break between weathered and unweathered rock can be remarkably harp.

It is estimated that 80 percent of the surface area of the western belt is underlain by saprolite, but the exact surface area of saprolite exposed, compared to the area of exposed hard rock, is unknown. For a small part of the belt, about 235 square miles in the Savannah River Catawba River district, it is estimated that 85 percent of exposed rock is saprolite. In the mountainous parts of the monazite belt the proporm . tion of exposed hard rock is greater. Of 417 auger holes drilled in the flood plains of the Savannah River a Catawba River district, 83 percent bottomed in saprolite, and 17 percent stopped on hard rock。 The average depth of the holes was 18 feet。

The upper surface of the saprolite may be exposed, it may be mantled by colluvium, or it may be covered by alluvium. The upper surface of the saprolite is a surface of erosion as shown by the unconformable superposition of sediments on saprolite at elevations several tens of feet above present stream beds. The nature and extent of the erosion, the time interval represented by the erosion, and the type of cover overlying saprolite are of fundamental importance in the geology of the monazite placers. 


\section{OFFICIAL USE ONLY}

32

The relation of saprolite to stream regimen, to shapes of flood plains, to the size fractions of detritus available for the formation of stream sediments, and to the development of monazite placers is discussed in separate sections below。

\section{Monąite in erystalline rocks}

The present investigation was restricted to monazite in stream sediments; few samples of exystalline rocks were taken. The distric bution of monazite in rocks of the belt was studied in reconnaissance by Mertie (1951, p。9, 15-19) and in detail in one quadrangle by Yates et alo, (1953)。 Data for the following discussion are drawn large ly from the detailed work。

Crystalline rocks as sources of monazite chorstalline rocks as sources of monazite were investigated by Yates and associates who took $I_{9} 250$ samples from rocks in the Shelby quadrangle, $N_{0} C_{0}$ con centrated the heavy minerals from the samples, and related the distric bution of monazite to the different rocks. A summary of their results is given in table 2 。

Monazite occurs with greatest frequency in the two granitic rocks. Monazite is less frequent in the metamorphosed sedimentary rocks of the Carolina gneiss where they are free of granitic material. A rise in the percentage of samples carrying monazite can be seen in those schists that have had granitic material introduced into them。 
Table 2,- Frequency distribution of monazite-wearing samples from rocks in the Shelby quadrangle, North Carolina (After R。 G。 Yates, W。 R。 Griffitts, and $W_{0}$ Co Overstreet)

Rock

Toluca quartz monzonite

Pegmatite from Toluca quartz monzonite

Sillimanite schist rich in granitic material

Biotite gneiss of the Carolina gneiss

Biotite schist rich in granitic material

Sillimanite schist of the Carolina gneiss

Biotite schist of the Carolina gneiss
Percent of monazite. bearing samples in total samples taken of each rock, (Frequency distribution)

Average monazite in rolume percent

.0026

84

.00152

80

.0027

75

.00185

73

.00137

54

.00076

* Represents averages of monazite-bearing samples only。 


\section{OFFICIAL USE ONLY}

34.4

It is difficult to establish an average tenor for a particular rock even after a great number of samples are taken. The amount of monazite in one type of rock ranges widely along and across the strike. Variations in the amount of contained monazite within one rock mass are as great as variations between separate masses of the same rock across 20 miles of country。 A wide overlapping in amounts of monazite persists from monazite-bearing samples of one type of rock to another type, but it is evident that monazite is less common in some rocks than in others. Comparison of frequency distribution of monazite. bearing samples and amounts of monazite in the samples reveals that, as sources for monazite, the erystalline rocks of the Shelby quadrangle can be ranked as shown in table 3 .

Table 3, cos Rank of crystalline rocks as sources of monazite, based on frequency distribution of monazite-bearing samples and on amounts of monazite in the samples。

(Modified from R。G。 Yates, W。R。Griflitts, and W。 Co Overstreet)

Rank

1. Toluca quartz monzonite and associated pegmatite

2. Biotite gneiss of the Carolina gneiss

3. Biotite schist rich in granitic material

4. Sillimanite schist rich in granitic material

5. Sillimanite schist of the Carolina gneiss

6. Biotite schist of the Carolina gneiss 


\section{OFFICIAL USE ONLY}

35

The actual importance of the different rocks as sources of monazite depends on their areal distribution as well as the frequency with which monazite occurs in them and its abundance where present. For the Shelby quadrangle as a whole a revision of the ranking shown in table 3 must be made. Weighing areas of outcrop with the other factors gives the order shown in table 4. This order is more generally applicable to the Savannah River - Catawba district than the order shown in table 3.

Table 4. Rank of crystalline rocks in the Shelby quadrangle as sources of monazite, based on frequency distribution, amounts of monazite, and area of outcrop.

(Modified from $R_{0} G_{0}$ Yates, $_{2} W_{0} R_{\circ}$ Griffitts $_{9}$ and $W_{0} C_{0}$ Overstreet)

Rank

Rock

1. Sillimanite schist rich in granitic material

2. Biotite schist rich in granitic material

3. Toluca quartz monzonite and associated pegmatite

40 Sillimanite schist of the Carolina gneiss

5. Biotite schist of the Carolina gneiss

6. Biotite gneiss of the Carolina gneiss

The mixed rocks; sillimanite schist and biotite schist into which quartz monzonite and pegmatite have been introduced, because of their wide areal extent and good incidence of monazite, outrank rocks of higher average tenor. Where the same metamorphic rocks are not widely injected by monazite-bearing granitic material they are relatively poor sources. 
Hornblende gneiss, hornblende schist, and dioritic rocks (Roan gneiss lithology) are rare in the Shelby quadrangle, but they are common in the northwestern and northeastern parts of the Savannah River Catawba River district. Samples taken from Roan gneiss are barren of monazite. Whatever monazite is found in streams draining areas underlain by Roan gneiss is inferred to have come from monazite-bearing granitic rock intrusive into the Roan gneiss and from monazite ubearing rocks of the Carolina gneiss interlayered with the Roan gneiss.

The other parts of the Savannah River - Catawba River district have a general structural and petrographic similarity to the Shelby quadrangle. Throughout the district the composition and relative proportion of accessory heavy minerals varies along and across the strike. Monazite-bearing granitic rocks differ in texture and structure; rocks similar to the Toluca quartz monzonite appear to be restricted to the northern half of the district. Proportions of the different schists and gneisses vary. The amount of sillimanite schist, biotite gneiss, and hornblende gneiss relatively barren in monazite rises in the southern part of the district.

Where present in rocks around Shelby, $\mathrm{N}_{0} \mathrm{C}_{0}$ monazite makes up 0.000006 to 0.034 percent by volume of the rock. It is probable that elsewhere the maximum is of the same order of magnitude. At one locality, the British Monazite Mine on Hickory Creek, Cleveland $\therefore$. . . County, No Co, biotite schist abundantly injected by pegmatite contained from "less than 0.03 " to "more than 1.1 percent" of monazite (Pratt, 1916, po 46)。 An unsuccessful effort was made to mine monazite 
from that rock. No area is known in the western belt where monazite might profitably be recovered from the crystalline rock。

In the Yadkin River - Dan River district the granite at Mt. Airy contains monazite, but it is thought that the phyllites, schists, and gneisses are barren of or very low in monazite. Monaziteubearing pegmatite is not as common in this district as it is in the areas farther south.

Monazite in the injection complex of the Oconee River district appears to be associated with the granite that crops out near Athens. Granitic bodies to the east and west, which are free of monazite, mark the boundaries of the belt.

Little is known about the crystalline rocks in the Flint River district as sources of monazite. Mertie $\left(1951, p_{0} .17\right)$ refers to the granitic rock in the area as a monazite bearing biotite quartz mon zonite rich in ilmenite.

In the Chattahoochee River district rocks of the Pine Mountain series are barren of monazite, whereas granite and gneiss north of the Towaliga fault carry monazite.

Throughout the five districts the richest source areas for monazite are underlain by high-rank metamorphic rocks into which granitic rock and pegmatite have been introduced。

Relation to associated minerals in placers. $\rightarrow$ The relations between monazite and associated minerals in placers reflect the types of crystaline rock in the distributive province of the stream and the depositional environment. A summary of the influence of sources on the 
suites of placer minerals is given here. Examples are taken from petrographically homogeneous distributive provinces, rare conditions that are restricted to the headwaters of small tributaries.

Fluvial concentrates derived from areas underlain by sillimanite schist commonly contain more sillimanite and ilmenite than concentrates derived from other sources. Garnet is abundant in streams draining areas of Toluca quartz monzonite and some gneisses. Monazite bearing concen trates from streams in Roan gneiss have large amounts of magnetite, 11 merite, amphiboles, and epidote. Many of the goldwbearing samples have come from areas in or bordering Roan gneiss. Some muscovite schist and sericite phyllite give staurolite. Typical associations of heavy minerals in placer concentrates from headwater tributaries in the belt are shown in table 5 .

Farther from the headwaters, where the area of the distributive prowince is largest, the source rocks ar more heterogeneous. Sorting action of the stream has had greater play $_{, \text {, }}$ and simple relations between the sources and the placers no longer obtain. Once introduced into the stream the more readily transported accessory minerals such as epidote $_{9}$

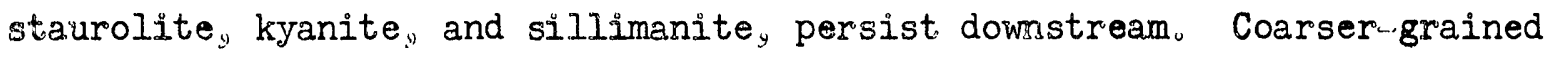
monazite lies near the source areas, finer grained monazite is dissipated downstream. The relations among the heavy minerals are then best ex - : plained by reference to the unconsolidated sediments in which they are deposited. Further discussion appears in the sections on Unconsolidated sediments and Placers. 


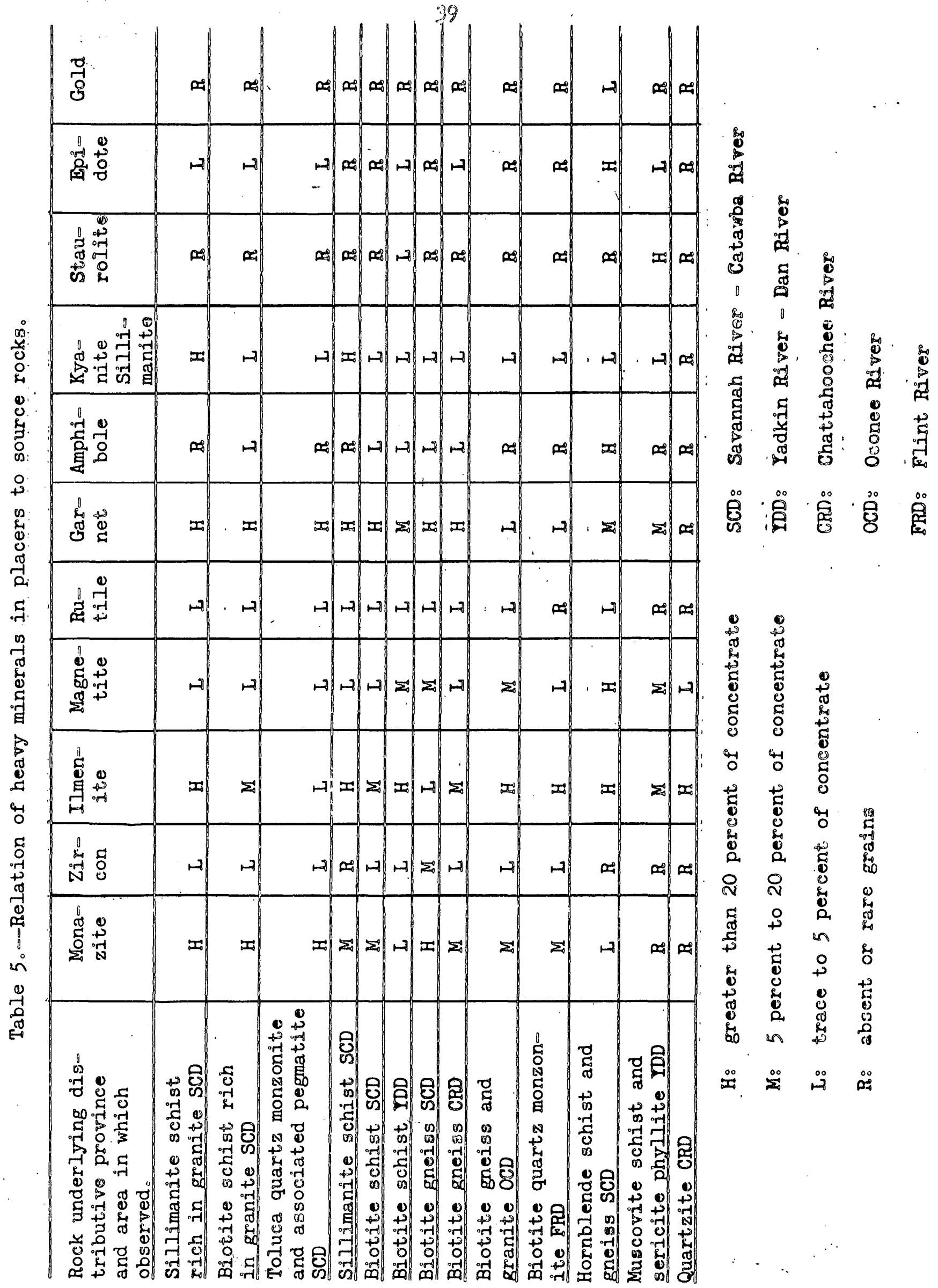




\section{Uncrisolindated sedinents}

The search for placer monazite and investigation of monazite deposits deals directly with alluvium and colluvium in the belt. Alluvium has received the greater attention in field work。

\section{Allluyia sedimentis}

Alluvial deposits in the southeastern Piedmont have been studied systematidally over the areas shown on plates 2 through 6 . Data on aliluviom in the monazite belt have been obtained from a study of exposures in stream banks, channel sediments, and churn and auger drilling。 Size classification of the sediments given here is based on field descriptions: size analyses of the sediments are being made but are not yet completed. Some uniformity in the sequence of flood plain sediments can be observed. A common sequence of sediments and their stratigraphic posi. tions follows:
(a) Sandy silt
(b) Silt
(c) Sand
(d) $\mathrm{Clay}_{9}$ often mucky or peaty
(*) Basal aggregate

These units vary in composition and appearance, but some consistent properties of each are described below. The order in which they are described follows stratigraphic position, from top to bottom。 


\section{OFFICIAL USE ONLY}

A reddish-brown or brown, sandy silt has the most uniform composition and distribution of the flood-plain sediments in the monazite belt. Sand may predominate, particularly where stratification is well developed。 Clay is present in smaller amount than either sand or silt; it rarely . exceeds 10 percent of the mixture. Flakes of mica are commonly abundant. In most exposures this sediment is from 1 to 5 feet thick, but it may be thicker in the flood plains of the largest streams. Rarely it is absent。

In some exposures a silt layer underlies the reddish-ubrown sandy silt. This silt ranges in color from buff to brown or gray: the color varies horizontally within a few feet. Materials of silt and clay size are dominant: with depth the percentage of clay commonly increases. Sand rarely exceeds 20 percent of the total. Mica flakes are abundant though not as common as in the overlying sandy silt. The silt layer in flood plains is generally at least as thick as the overlying sandy silt, but it may also be absent。

Volumetrically sand is the most abundant flood.plain sediment in the monazite belt, but it is neither the most persistent nor the most uniform. of the sediments. It commonly overlies a clay layer, but it may be prese ent anywhere in the sequence. At some places it is the only sediment in the flood plain notably in large downstream flood plains of the Pacolet River in Spartanburg County,, $\mathrm{S}_{\circ} \mathrm{C}_{\circ}$, where a fllood in 1916 swept out all other sediments and deposited 15 to 20 feet of sand. In many areas the sand occurs as lenticular bodies. The sand ranges in sige from granule sand to very fine sand. It is commonly brown to buff in color. but is also gray to white。 


\section{OFFICIAL USE ONLY}

The floodaplain sediment having the widest range of physical characteristiçs is the clay which lies stratigraphically beneath the silt or sand and over the basal aggregate. Clay is used as a textural term with no compositional implication. In some places the clay is blue gray and has uniform texture: elsewhere it is a dark gray or black muck containing abundant fragments of fresh or carbonized wood or peaty vegetal debris. Clay in many exposures contains abundant fine white sand and scattered angular pebbles of quartz. The clay almost invariably overlies basal aggregate or, if the basal aggregate is absent, over. lies bedrock。

The basal aggregate is a quartz pebble gravel with minor amounts of feldspar and rock fragments all bound in a matrix of white, yellow, or buff sandy clay。 Rock fragments increase in abundance in the gravel as the headwaters of a stream are approached. Among the pebbles and cobbles of the basal aggregate all degrees of angularity are represented with sub angular to suburounded fragments most abundant. The average maximum dimension of pebbles in the gravel is 2 inches, but cobbles up to 6 inches are common. The distribution of basal gravel in flood plains is irregular: in any flood plain close to headwater areas the gravel is commonly persistent but variable in thickness: in flood plains farther downstream the gravel is discontinuous and thin. The basal gravel in flood plains of the belt contains richer concentrations of monazite than the other alluvial sediments. 
Fluvial gravels other than the basal aggregate have been found in the belt. Locally an accumulation of gravel overlies the clay layer. suggesting that the upper surface of the clay has been eroded. Road cuts and other excavations locally expose sediments of old stream valleys containing gravel layers analogous to the basal aggregate in the flood plains but at levels higher than present stream beds.

Thickness and relationships of flood plain sediments.... Viewed in detail the thickness of the various sediments is not constant along or acrose any given flood plain, or among llood plains. Units pinch and swell or may be absent. Figures compiled from all auger drill logs show an arerage thickness of 3.5 feet for silt, 5.7 feet for sand 4.0 feet for clay, and 1.0 soot for gravel in flood plains of all sizes in the Savanmah RIver - Catawba River district. Recast as percentages of the total thickness of flood plain sediments the footages given above become 25 percent of silt, 40 percent of sand in all grades, 28 percent of clay: and 7 percent of pebble gravel and coarser debris. Grades ranging from coarse sand through all sizes of gravel are estimated to compose 15 per. cent of the total thickness of the average sequence of stream sediments. Broadly riewed throughout the belt, flood plains near the headwaters of streams consistently have a greater proportion of coarse clase ties to finerwgrained sediments than do flood plains farther downstream in areas of lower relief and gentler gradient. There is a great increase in the amount of sand and silt deposited downstream. Thus, the thinning basal aggregate is buried under a layer of foine grained overburden that 
is progressively thicker downstream. From the same broad viewpoint, finero grained sediments are more common in the eastern than in the western part of the belt, and are more common in the southern than in the northern part of the belt。

Available detritus por coarse sediments. gullying oupply most of the detritus available for alluvial deposition. Happ and coworkers $\left(1940, p_{0}, 76\right)$ point out that of the two gullying is more important because it usually delivero the waste directiy to streams, whereas much debris from sheet erosion lodges on the lower hill oloper: They further point out that, although sheet erosion aplects only surficial material, guldying suts into deeper matorial. Ins the belt, where saprolite underlies 80 percent of the surface, gullying thsough colluvium into saprolite makes avaxlable to the streams large rolumss of Pine grained detritus. Irs saprolïtized areas rare fragments of unweathered roek and quartz from veins and pegmatite are the only debris available to form gravel. Thus, largewized pasticles are an initually gmall part of the load in streams.

Age of alluvium $=-$ The age of flood plain sediments in the belt is thought to be post.Wisconsin. The sediments are divisible into a late Recent (modern) sequence of reddish brown, sandy silt which has accumu lated since sarming was introduced in the area, and an older Recento (premodern) sequence underlying the upper sandy oilt. The typical reddish brown color of the upper sandy silt, as contrasted to the buff or gray colors in the underlying sediments, is a criterion, though not an infallible one (Happ, Rittenhouse, and Dobson, 1940, p.65), for 
establishing the break between modern and pre-modern sediments. Happ and associates (1940, p. 65) also note that hard ferruginous concretions are associated with the pre-modern material only. Such concretions have been seen in the lower sediments of the monazite belt, but they are not common.

In the extreme headwaters of several streams in the Savannah River ... Catawba River district, deposits of peat and clay have been found that contain spruce and fir pollen. Pollen analyses indicate that these sediments are late Pleistocene in age. These Pleistocene sediments are relatively rare and survive only in isolated upland depressions that have escaped erosion. Pollen analyses were made on 18 samples of peat, carm bonaceous clay, and carbonaceous sand from the lowest beds of downstream flood $\propto$ plain sediments in the same district. Pollen in these sediments is similar to pollen falling at the present time d.

\section{d Barghoorn, Elso, written communication, January 1953.}

\section{Relation of monazite to alluvium}

Generally the richest concentrations of monazite in alluvium within the belt are in the basal aggregate and in the gravel of the present stream channels. Poorly-sorted alluvium contains coarserugrained monazite than does well-sorted material. Silts and clays commonly carry small concentrations of fine-grained monazite, which explains the low average tenor of large downstream flood plains where the basal aggre gate may be buried under 20 feet or more of fine-urained sediment. 
In detritus derived from the better source areas the finer...grained sediments contain from 0.01 to 1.5 pounds of monazite to the cubic yard and average about 0.3 pound of monazite to the cubic yardo Coarse-grained sediments contain about 10 times that range and average of monazite. It is rare for the total sequence of sediments from grass roots to bedrock to average more than 2 pounds of monazite to the cubic yard. A general average in the better.situated of the larger flood plains is about 0.75 pound. Where the average reaches 2 pounds of monazite to the cubic yard the proportion of coarser clastics to total thickness of 2lluvium exceeds 15 percent, the coarser sediment averages more than 3 pounds of monazite to the cubic yard, and the finer clastics average about 0.5 pound of monazite to the cubic yard。

The distribution of monazite in relation to the grain size of fluvial sediments can be related to the mode of deposition of the sediment. Happ and associates $(1940$, p. 22-31) describe six genetic types of modern flood-plain deposits in the southeast: four types account for 90 percent of the modern and pre-modern sediments in the belt. Their origin explains the low tenor of the fine grained sediments and the higher tenor of the coarse sediments. These four types are "channel-fill deposits", "vertical accretion deposits". "lateral accretion deposits", and "channel-lag deposits"。

Channel-fill deposits accumulate in stream channels where deposition exceeds transporting capacity。 The deposits represent a net accumulation from scouring during rising flood stages and deposition during falling stages. Old silts of vertical accretion commonly overlie 
channel-fill deposits, a relationship that suggests lateral migration of the stream channel was important in the formation of premodern stream sediments (Happ, Rittenhouse, and Dobson, 1940, p。23)

Vertical accretion deposits are described by Happ and cosworkers $\left(1940, p_{0} 24\right)$ as fine-grained sediments deposited from suspended load in the water spreading out on flood plains during periods of overbank flooding。

Lateral accretion deposits are defined (Happ, Rittensouse, and Dobson, $1940, p, 25)$ as those "Formed along the sides of channels, where bed load material is moved by traction toward the inner sides of channel bends. Normally such deposits of lateral accretion are later covered by finer material of vertical accretion, as the channel shifts farther away by lateral bank cutting so that the slipworf slope on the inside of the bend is overflowed less frequently and with less velocity。 The deposits of lateral accretion are coarser than those of vertical accre ... tion, but they are finer, on the average, than the channel-fill or channel-lag deposits because of a greater admixture of material deposited from suspension in the shallow water on the slip off slope of the channel side ${ }^{\text {" }}$

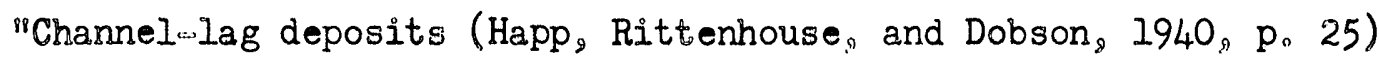
are composed of the relatively coarser therials that have been sorted out and left as a residual accumulation in the normal process of stream action. They are predominantly developed in the beds of most streams but do not indicate channel aggradation, as do the channel:sill deposits. 


\section{OFFICTAL USE ONLY}

48

These lag sediments also tend to be mixed with the deposits of lateral accretion, but in many places there is considerable residual accumulation of the coarsest sediment in the deeper parts of the main channel and in parts of the stream where lateral accretion is not active。 Such residual accumulations are genetically distinct and can often be recognized textur ally where exposed in cut banks after burial and reexcavation. They are typically found at the base of the vertical flood-plain sequence: although in an aggrading valley. lag deposits may be found in old buried channels at any vertical position in the valley alluvium below the latest surface cover of vertical accumulation."

Sediments formed by vertical accretion and channel fill include about three-quarters of the volume of alluvium in a flood plain. Vertical accretion deposits contain finer"grained and less-abundant mona zite than the other sediments because they are deposited from suspended load composed chiefly of small particles of low specific gravity. Channelfill sediments deposited during falling fllood stages range widely in contained monazite, are commonly richer than the deposits of vertical accretion, and are leaner than lateral accretion and channel-sag sediments。 Lateral accretion and channel-lag deposits make up about 15 percent of the volume of alluvium in flood plains of the belt and include practirs cally all the coarseragrained debris. Active sorting in the depositional environment of these two types of sediment favors concentration of parti. cles in the coarser grades and higher ranges of specific gravity。 
Colluvial sediments and residual deposits

The term colluvial sediment, as used in this report, refers to poorly sorted, unconsolidated erosional debris derived from saprolite, hard rock, or old stream deposits, and transported by wash, soil creep, and frost action to accumulate on slopes. Included in this definition are sheetwash deposits and sediments collected in gullies, ravines, and swales during present and earlier erosional ycles. Exeluded from the definition are residual deposits of cilayey sand and rock fragments that have locally accumulated in place from the disintegration of saprolite and hard rook. Residual deposics are on interstream divides; colluvial sediments are commonly on hilloides and in depressionz.

Colluvial sediments.-Coluvial sediments are best exposed in erosion guli.ies and headwater reacheis of smaller streams. No stratigraphic sequence for colluvial deposits has yet been worked out but some relar tions have been noted.

Quily sedineriog of powsible prewazonsin age have been desuribed (Cain, 1944, po 19-20) in Spartanburg County, $S_{0} C_{0}$ Similar deposits have been öserved throughout the Savannah River ' Catawba River district. None was noted in the Yadkin River ... Dan River district, but it is possible some may be found there. In the Oconee River district, the Flint River district, and the Chattahoochee River district relief is low and erosion gullies are too shallow to expose identifiable sections of older colluvium. The most complete sections in the Savannah River - Catawba River district are in deposits formed in old, probably ponded, gullies, ravines, and swales. Incomplete sections were developed in unponded gullies and swales。 


\section{OFFICIAL USE ONLY}

A typical complete section of older colluvium consists of a basal layer of clayey gravel resting on saprolite or hard rock. This is overo lain by muck which, in turn, is overlain by mixtures of bedded to unsorted sand and clay. The colluvium ranges in thickness from 10 to 30 feet. Gravel and muck rarely account for more than 15 percent of the total thickness。

At many places muck and gravel are absent, and bedrock is directly overlain by poorly sorted clay and sand. These incomplete sequences probably werc developed in unponded depressions.

The gully deposits lens out or grade into sheet-wash deposits up the flanks of adjoining hills but continue headward into, or near, present interstrearn divides where they merge with sheet=wash debris. Older gully sediments, at the few observed contacts, appear to be overlain unconformably by alluvial deposits of the stream valleys.

Sheetwash deposits on the slopes of hills are the most widespreadi. and typical of the colluvial sediments. They have been observed in all five districts. Along the flanks of hills they unconformably overilie saprolite or hard rock. Locally, the base of deposits formed by sheet wash is marked by a thin, discontinuous layer of angular fragments of quartz with which are a few water-worn quartz pebbles and rare blocks of unweathered bedrock. The few streamworn pebbles are derived from small, isolated, older fluvial deposits of higher elevation. Angular fragments of quartz and bedrock come from local sources. The overlying clayey sand commonly is unsorted, but it may be poorly and discontinuously bedded. 
Sheetwwash deposits lens out uphill or merge imperceptibly with residual deposits of the divides. Downhill they grade into and overlie colluvium in gullies, and they are truncated by or lap upon alluvial deposits of the valleys. Sheet - wash deposits probably range widely in age: some appear to be as old as the older gully sediments; other deposits are clearly being formed by present accelerated erosion。

A greater range and more profound development of soil profiles was noted by Denny and Malde / in colluvial deposits of the Shelby area, $N_{0} C_{0}$,

/ Deruny, Co So, and Malde, $\mathrm{H}_{0} \mathrm{E}_{0}, 1953$, oral communication.

than in the alluvial sediments. In part at least, this appears to re... flect the greater age of some colluvial sediments.

Residual deposits - -Residual deposits that appear chiefly to have developed through the disintegration in place of saprolite form mantles 1 to 7 feet thick in many interstream areas. These deposits have been noted in all five districts. Neither texture nor structure of the saprolite is preserved. Few clues to the type of parent rock can be found except through a study of heavy minerals in the residuum. Residual accumulations grade downslope into colluvial deposits.

Relation of monazite to colluvial sediments and residual deposits

Colluvial deposits may be the source of local enrichment of fluvial

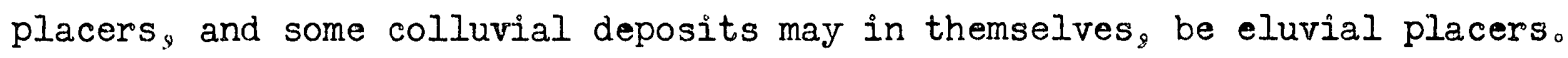
At this writing scant evidence has been gathered to support that view, but 
some expression of it will be given to point up a possible relation between monazite and colluvial sediments。

The best data are those obtained from drill hole number K26 sunk by the U.S. Bureau of Mines, December $27-28,1951$, on the upper western flank of an interstream area on the Bradshaw farm in the Knob Creek drainage, Cleveland County, N, Co The hole penetrated 20.5 feet of bouldery colluvium that averaged (field estimate by $U$ 。 S。 Bureau of Mines) 2.1 pounds of monazite to the cubic yard and ranged from 1.5 to 2.8 pounds of monazite to the cubic yard. Other data are from grab samples taken

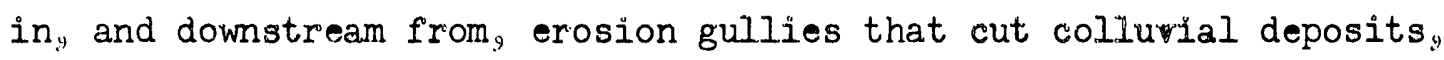
and from the relation of old monazite mines to colluvial deposits.

Colluvial sediments and residual deposits, at least locally, cono tain monazite in concentrations 10 to 15 times greater than the parent crystalline rock. Downward from the upper surface to the base of a se quence of colluvial sediment, the distribution of monazite is more uniform than it is in the alluvial sediments. The tenor of some colluvial deposits is less than the tenor of upstream gravel, is slightly higher than the average of upstream alluvium, and is two or three times greater than the average of all alluvium in a large flood plain.

Many sites formerly mined for monazite are along stretches of streams to which mosts tributaries are gullies that sut collyrium. Some ild monazite mines were actually restricted to long, narrow gullies that expose only colluvium. Some colluvial deposits: expecially sheet $\rightarrow$ wash sediment. were mined, 


\section{OFFICIAL USE ONLY}

\section{3}

Colluvial sediments and residual deposits are the intermediate host for monazite between the crystalline bedrock and the alluvial sedio ment. Not all monazite in alluvium passed through colluvial sediments before being released to the streams. Present erosion exposes saprolite in gullies and banks of streams to permit the heary minerals to be con centrated directly in the streams. However, those streams that are re called by miners as sites of richest fluvial deposits of monazite are streams receiving drainage from proportionately larger areas of colluvium and smaller areas of saprolite. Even in intermediate and large-sized. fllood plains some richer lenses of sediment appear to be related to locall: derived detritus swept into the flood plain from an adjoining gully that cuts colluvium. In some intermediate-sized flood plains, where the finer grained sediments have a relatively high average tenor. the adjoining hillsides are steep and local drainage brings in debris from sheet-wash deposits.

It appears that processes forming colluvial sediments and residual deposits have produced an initial concentration of monazite greater than that obtaining in bedrock, and that reworking of colluvium by the streams results in a higher tenor alluvium than fluvial sorting of sediment derived directly from saprolite。

\section{Geomorphology}

The monazite belt is in the Piedmont province: some outliers of the Blue Ridge, notably the South Mountains in North Carolina, are within the west margin of the belt. In the belt, monadrocks like Paris Mountain 
in Greenville County, S. C., project above the level of summits of hills and interstream areas. Coastal Plain sediments are 25 miles east of the east margin of the belt in the Chattahoochee River district and are 150 miles east of the Yadkin River - Dan River district。

\section{Geomorphic factors}

Relief。about 150 to 200 feet. This relief becomes greater along the west boundaxy of the belt where that boundary includes oulliers of the Blue Ridge. The maximum local relief in the Savannah River - Catawba River district is 1,600 feet in Burke County, No C, Altitudes in the Savannah River - Catawba River district range from 600 feet above sea level in southeastern Spartanburg County. $S_{0} C_{\text {. . . to }} 2,919$ f'eet on Walker Knob in the South Mountains south-southeast of Morganton, Burke County, $N, C$. In the three districts in Georgia the maximum and minimum altitudes are generally Lower than those in the Savannah River - Catawba Rïrer district. The Yadkin River - Dan River district has maximum and minimum altitudes higher than those in the Savannah River - Catawba River district. In all the districts the altitudes of the Piedmont surface increase from the southeast to the northwest across the belt.

Streams.- The headwaters of most of the major rivers in the Piedmont are in the Blue Ridge and are subsequent to the structure of the Blue Ridge. In their downstream portions on the Piedmont and the Coastal Plain the major rivers are consequent to the regional slope of the land surface。 
Streams tributary to the major rivers range in size from small insequent streams a few thousand feet in length to large streams with drainage basins 40 miles in longest dimension. Dendritic stream pattern is dominant in the belt although there is a suggestion of rectangular pattern and structural control in some areas.

Stream gradients of the major rivers range from 19 feet per mile on the Enoree River from its headwaters downstream for 26 miles to 43 feet per mile on the First Broad River from its headwaters downstream for 36 miles. On the Piedmont surface, downstream from their headwaters, these rivers have gradients of 10 to 15 feet per mile. The longitudinal profile is generally even, but it is locally steepened where hard bedrock crops out in the stream channel. At these places the stream bed is low ered 20 to 40 feet over a distance of 1,000 feet. Gradients of the heado water tributaries to major rivers and headwater tributaries to the larger tributary streams range from 30 to 75 feet per mile. Some headwater tributaries draining the mountains and monadnocks in the belt attain a gradient of 155 feet per mile。

Commonly there is a local increase in gradient of tributary streams as they approach major rivers. This increase in gradient may represent rejuvenation of the major rivers. A tributary stream, having less energy than the river, cannot keep pace with the down cutting of the river and develops an area of rapids and shoals near its mouth. There is a decrease in gradient on a tributary stream from the rapids to its mouth in order that the gradient may conform with the lower gradient of the river, Rela tively resistant bedrock may cause rapids in a stream near its mouth without 


\section{OFFICIAL USE ONLY}

56

any rejuvenation of that stream. Graded reaches, produced by an outcrop of resistant hard bedrock in areas of saprolite, are common at many places along tributary streams.

Many of the tributary streams are mature but have youthful areas in their headwaters, in downstream portions of graded reaches, and near their mouths. In the Chattahoochee River district and the Flint River district in Georgia the larger streams are approaching old age. In many places along these streams there is little flow of water and the channel sediments are thick accumulations of mud。

Flood plains.-..The sizes and shapes of flood plains are controlled. mainly by the distribution of saprolite. Wide flood plains are generally underlain by saprolite rather than hard bedrock. Narrow flood plains, constricted channels, and gorges are in hard bedrock. Stream patterns of obvious structural control, such as Mountain Creek in Harris County. Ga.s are developed in areas where hard bedrock dominates over saprolite. Where resistant bedrock crops out in a stream channel downstream from an area of saprolite a graded reach is developed. Some of the largest flood plains in the belt are in graded reaches。

Transverse profiles of flood plains, based on auger holes drilled in 69 flood plains of all sizes in the Savannah River - Catawba River district, are commonly shallow and Uwshaped. In many flood plains the valley floor is nearly flat. Some valley floors are deeply channelled locally and have a well-developed slip-off slope leading into the channel. The average depth of the valley floor beneath the present surface of the flood plain for all holes drilled is 14.5 feet. 
For purposes of this preliminary discussion flood plains in the western monazite belt are described as: ( 1 ) small if they contain less than $I$ million cubic yards of fill, (2) intermediate if they contain I to 10 million cubic yards of fill, and (3) large if the total volume of alluvium exceeds 10 million cubic yards. The physical characteristics of several small, intermediate, and large flood plains are summarized in table 6 below. Few continuous flood plains in the belt contain more than 10 million cubic yards of alluvium. Most of those that exceed 10 million cubic yards in volume are along the east boundary of the belt and the majority are in South Carolina and Georgia. The greater number of large flood plains in the southeastern part of the belt reflects the lower relative relief and gentler gradients there。

\section{Relation of monazite to geomorphology}

Fluvial deposits containing the highest concentrations of monazite are gravels in the stream channel in headwaters where gradients range from 30 to 155 feet per mile. Streams in these areas are youthful. Valm leys are $V \omega$ shaped, flood plains are imperfectly developed or absent, and the stream flows on bedrock or coarse gravel. A rapids-pool type of stream bed commonly develops where bedrock is differentially resistant to erosion.

Downstream from these areas of highest concentration the gradients become less steep; flood plains are more common and are larger; finer-grained sediments are more abundant; and the average tenor of the monazite placers decreases. 
OFEICIAT USE ONLYY

58

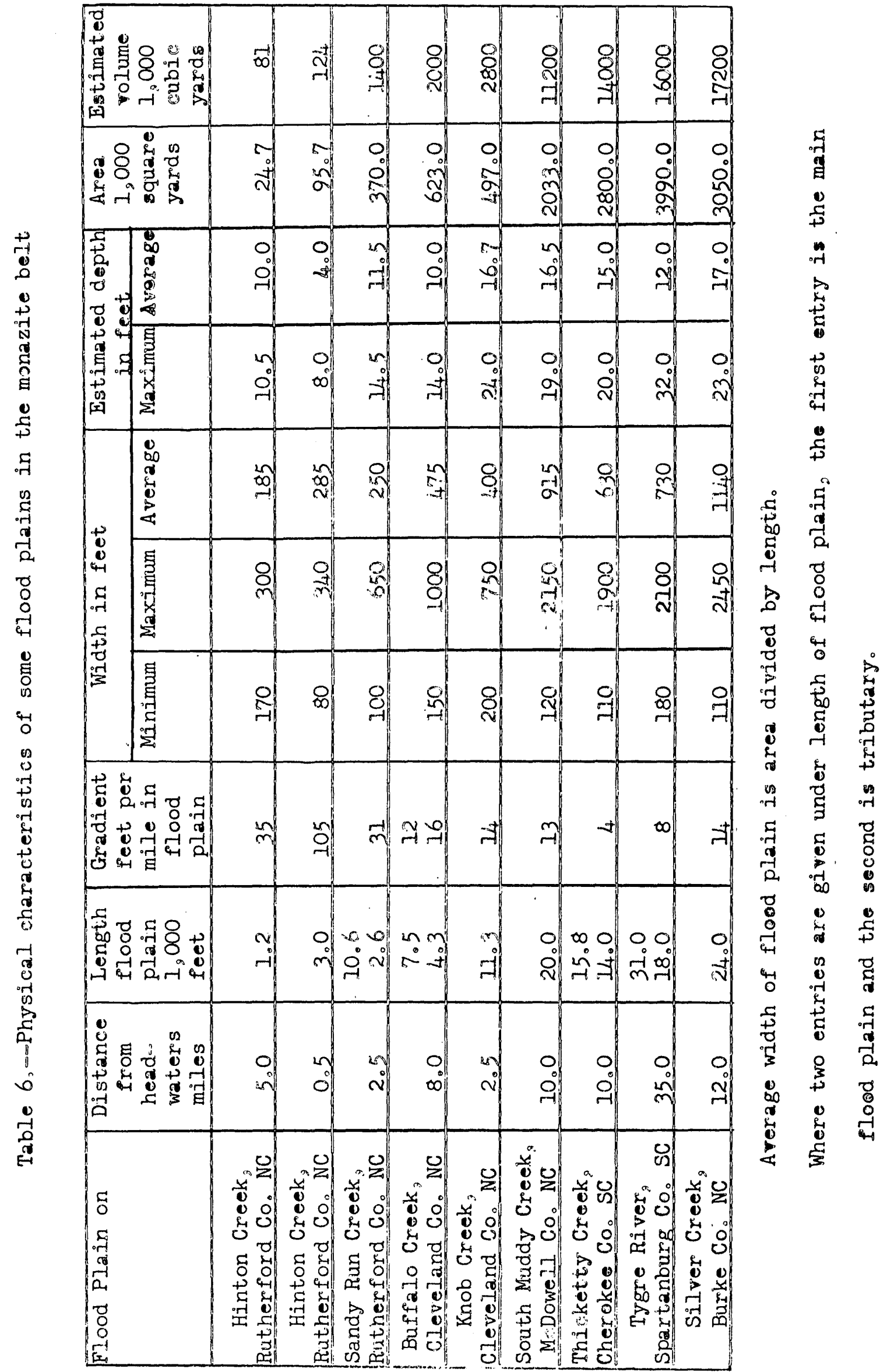


The general altitude of the Piedmont is too close to the base level of the Atlantic Ocean for streams to develop great erosive power. Inside the monazite belt the Piedmont averages 800 feet in altitude and is 200 miles from the coast. The average regional slope of the land is 4 feet per mile. Stream energy developed on this low slope has been too small for erosion to overtake weathering. Conditions of erosion and stream transportation do not favor the formation of rich placers in large flood plains.

\section{PLACERS}

The term placer, as used in this report, means simply a concentration of heavy minerals in alluvial or colluvial sediments with no economic implication. Concentration of heavy minerals in a sediment over that in an equal volume of bedrock has been effected by gravity separation of heavy minerals from associated lighter minerals. A placer includes both the heavy minerals and their sedimentary host, A placer may or may not be minable. In the monazite belt the most sommon heavy minerals in placers are ilmenite, magnetite, garnet, monazite, zircon, and sillimanite. Locally, kyanite, staurolite, and epidote are abundant in the heavy mineral fraction. Small amounts of gold may be present. The weight of monazite in the placers ranges from 0.01 pound to 40 pounds per cubic yard and is in inverse ratio to the size of the flood plain and the thickness of fine-grained sediment。

Two types of alluvial placers were studied: source placers and reserve placers. Source placers are those formed in stream sediments 
near the source rocks and are in headwater areas. Individually this type of placer is not quantitatively significant, but it is a valuable guide to possible reserve placers。 Reserve placers are those in the larger down stream flood plains. These placers are inferior to source placers in tenor of monazite, but because of their volume they are a possible poten. tial for large scale, low-unit-cost mining operations. Some source placers have been mined: reserve placers have not been mined。

The search for monazite in minable quantities involves the locating of flood plains which are favorably situated with respect to streams draining rich source rocks. Placers containing monazite are irregularly distributed in a belt 10 to 50 miles wide extending from Virginia through Alabama in the western Piedmont. The frequency distribution of these placers varies not only anong major drainages but among tributaries to the same drainage and among reaches of the same tributary. The tenor of monazitc ranges widely in sediments of similar lithology and texture over short distances along streams Some of the distributive irregularity is attributed to variable: local, sedimentary conditions, but the pattern of placer distribution compared with mineralogical analyses of the bedw rock suggests that the irregular occurrence of monazite in the sediments is a reflection of the distribution of monazite in the source rocks. The demonstrated drop in tenor of fluvial sediments between head.. waters and trunk drainage shows that in the present cycle of aggradation monazite is subject to dispersive and dilutive influences toward the larger rivers. Highest concentrations of monazite, which rarely attain 40 pounds to the cubic yard, are in thousands of small placers at the 


\section{OFFICIAL USE ONLY}

61.

extreme headwaters of streams rising in the belt. The concentration of monazite drops off abruptly as flood plains larger than 1 million cubic yards are developed a few miles downstream from stream headwaters: Alluvium in the farthest-upstream intermediate sized flood plains commonly averages about 1.5 pounds of monazite per cubic yard. This abrupt de.. crease from tenors that obtain in headwaters cannot be attributed largely to influx of monazite poor sediments from differnt distributive provinces. Other causes of downstream decrease in tenor are: (1) colange in gyadeng of the stream to which are related the rate of tronsportation of monazite and the decrease in thickness of coarser sediment, (2) brittleness of monazite compared to other heavy minerals which allows ready communutions and dissipation of monazite, and (3) increase in rolative volume of deposits formed by vertical accretion giving rise to thicker, low tenor overburden. Following this abrupt. reduction in terior near headwaters, the average tenor of flood-plain sediment in the larger streams gradually diminishes toward the mouth。 On Buffalo Creek in Cleveland County, N。C.o and Cherokee County, $S_{0} C_{0}$ it diminishes from 1.2 pounds to 0.3 pound per cubic yard along 30 miles of stream. In trunk drainage, as the size and number of tributaries increase, adulteration by suites of heavy minerals from monazite-free areas becomes dominant. Thus the larger the flood plain and the farther it lies downstream, the lower is its average tenor of monazite.

Placer deposits in the individual drainage systems of the five disw tricts (plates 2-6) are discussed below. Because laboratory examination of samples is not completed, the discussion presented is based on field estimates。 


\section{OFFICIAL USE ONLY}

52

\section{Placers in the Savannah River _. Catawba River district}

\section{Savannah River drainage}

The Tugaloo River and the Seneca River are confluent about 10 miles inside the western boundary of the belt and there form the Savannah River. The Tugaloo and Seneca Rivers head in the Blue Ridge about 50 miles north and northwest of the belt.

Little River, wo Tributaries to the Savannah River drain only three areas of source rocks rich in monazite. Placer samples from tributaries to the Little River near Honea Path, S。Cog and Due West, $S_{0} C_{0}$, are rich in monazite. There are no large or inter... mediate flood plains on the Little River or its tributaries within the belt. About 10 miles downstream from the point of emergence of the Little River from the monazite belt. ${ }_{9}$ several intermediate flood plains are developed. Within the belt there are several small flood plains on the Little River and its tributaries.

Rocky River.wA few miles west and southwest, of Williamston, S。O.g headwater tributaries to the Rocky River drain a small area rich in monazite. Source placer samples from small tributaries to Broadway Creek and Little Beaverdam Oreek are rich in monazite. There are several flood plains of intermediate size along Little Beaverdam Creek and the Rocky River near Anderson, S。C。 No large flood plains are in this drainage。 There are many flood plains of less than 1 million cubic yards on the tributaries to Broadway Creek, Little Beaverdam Creek and the Rocky River。 
Big Generostee Creek. $\rightarrow$ Big Generostee Creek was recommended (Overstreet, 1952b, p。 8) to the U。 S。 Bureau of Mines as a site for churn drilling. An estimated total of 24 million cubic yards of allua vium is contained in the main stream and its largest tributary, Moun tain Creek, in Anderson County,$S_{\circ}$. C. This total alluvium comprises several flood plains of intermediate size but none of large size (plate 7). No placer sample from the main stream or its tributaries contains more than an estimated 5 percent of monazite in the concentrate. Especially large volumes of concentrate were obtained rrom samples taken on Mountain Creek, but they contained low percentages of monazite。

Big Beaverdam Creek。-Big Beaverdam Creek in Anderson County, S。Co, is a tributary to the Tugaloo River and is the only stream tributary to the Savannah River which has a large flood plain in an area of monaztes rich rock. The best samples of placer monazite come from headwater tributaries 5 to 10 miles upstream from the large flood plain. In the immediate area of this flood plain, tributaries to Big Beaverdam Creek give samples having only fair concentrations of monazite. Upstream at the confluence of Cleveland Creek and Big Beaverdam Creek in. Oconee County, $\mathrm{S}_{0} \mathrm{C}_{\circ}$ is an intermediate flood plain nearer the monazite-rich source rocks than the large flood plain. Streams draining the same source area have developed several intermediate and many small flood plains on Little Beaverdam Creek.

Tributaries to the Seneca River.--Field estimates of samples taken from tributaries to the Seneca River show no source area rich in monazite. There is one large flood plain on Twenty-three Mile Creek. Along the 
courses of Eighteen Mile, Twenty-three Mile, and Twenty-six Mile Creeks aro soveral intermediate flood plains and many small flood plains. All aro vory low in monazite.

\section{Saluda River drainage}

Saluda River and smaller tributaries.... The Saluda River heads in the B!uo Ridge about 25 miles north of the west boundary of the monazite wit. For 40 miles along its course within the belt, tributary streams drain areas of monazite-bearing rock. Nost of the smaller streams tributary to the Saluda River inside the belt give samples rich in rilonazite, Broad Mouth Creek, near Honea Path, $S_{0} C_{c}$, has one flood plain that contains about 3 million cubic yards of alluvium in an area of monizito-rich bedrock. No other stream tributary to the Saluda River h?s developed flood plains containing more than 1 million cubic yards of alluvium.

Along the Saluda River itself are many small and intermediate flood plains. Gravel and coarse sand has accumulated on many of the s.lip-ofi slopes within the river channel. The heavy-mineral concentrate from a sample taken from the largest of these deposits, estimated to he: 50,000 cubic yards of coarse sand and gravel, contained about 5 porcent of monazite. Since there is no over burden on these slip-off slopes the volume of gravel is comparable to that found in a greater ". rolume of flood-plain sediments. 
Reedy River. - The Reedy River is the largest drainage tributary to the Saluda River. The Reedy River heads north of Greenville, S。 Co, about 10 miles north of the west boundary of the monazite belt. From Greenville southward to its confluence with the Saluda River, tribu-s taries to the Reedy River drain areas of monazitembearing bedrock. No one continuous flood plain on the tributary streams contains more than I million cubic yards of alluvium. Most of the small tributaries, especially those of Huff Creek, are rich in monazite. Concentrates of heavy minerals from several of these small tributaries contain more than 50 percent of monazite. Flood plains along the Reedy River are small intermediate and widely spaced。

Rabon Creek - -North and South Rabon Creeks join near the southerrs boundary of the monazite belt and there form Rabon Creek, the largest tributary to the Reedy River. Several disconnected flood plains of intermediate size and many small flood plains along North and South Rabon Creeks have an estimated total of 35 million cubic yards of allu-s vium, but no one continuous flood plain contains more than 5 million cubic yards. Most of the streams tributary to North Rabon and South Rabon Creeks contribute monazite to the main stream. Samples taken from several of the smaller tributaries contain up to 50 percent of monazite in the concentrate. The headwaters of both streams drain an area of monazite-free bedrock. A part of North Rabon and South Rabon Creeks (plate 8) was recommended for drilling (Overstreet, 1952b, p. 6) 
Source placers of monazite are common in the drainage basin of the Enoree River for 20 miles downstream from its headwaters in Greenville County, S。C. The tenor in monazite is unusually high in the sediments of Gilder Creek, Rocky Creek, and a group of small tributaries to the Enoree River in the vicinity of Buckhorn Creek, Greenville County, S。C. Large flood plains have formed in the lower reaches of Durbin Creek and on the Enoree River several miles upstream from the mouth of Durbin Creek in Laurens County, SoC。 Although source placers of monazite are plentiful upstream from the flood plains on Durbin Creek, tenor of the flood plain is not high.

The Enoree River flood plains are favorably located with respect to the monazite belt. At the site of these flood plains the river has a drainage area of 270 square miles inside the belt.

Small fllood plains occur on the main river near the mouths of Gilder Creek and Mountain $\mathrm{Creek}_{y}$ and along the middle reaches of Gilder Creek in Greenville County, S。C。All these flood plains are receiving sediment that contains above average quantities of monazite. Other small flood plains that contain nearly 1 million cubic yards of alluvium each are along Abners Creek, Brushy Creek, Rocky Creek, and in the upper reaches of Durbin Creek, South Durbin Creek, and Gilder Creek. 


\section{OFFICIAL USE ONLY}

Tygre River drainage

South Tygre River. - The southeast margin of the monazite belt crosses the Tygre River system about 3 miles upstream from the confluence of the North and South Tygre Rivers in Spartanburg County, S. C。 The northwest margin of the belt crosses the South Tygre River 7 miles downstream from headwaters。 Tributaries contribute monazite bearing sediment to the main stream for a distance of 25 miles along its course. Source placers are very rich in monazite on Bens Creek and on several small tributaries to the South Tygre River upstream from Bens Creek。 The only large flood plain on the South Tygre River is 7 miles upstream from the junction of the North and South Tygre Rivers. Several small flood plains áre along the middle reaches of Ferguson Creek。 Small flood plains on the main river and on other tributary streams to the South Tygre River are not quantitatively important。

North and Middle Tygre Rivers.a The North Tygre River heads near the northwest margin of the belt in Spartanburg County, $S_{0} C_{0}$, and flows 16.5 miles through the belt to join the South Tygre River 3 miles upstream from the southeast margin of the belt. The Middle Tygre River rises in the Blue Ridge in Greenville County, $\mathrm{S}_{0} \mathrm{C}_{0}$, and flows 18 miles across the belt to join the North Tygre River near the southeast margin of the belt.

One of the largest flood plains in Spartanburg County, S。C。g is on the North Tygre River at the confluence of the North and Middle Tygre Rivers (plate 9) and extends 3.5 miles downstream. At the 
upstream end of the flood plain the rivers drain 85 square miles of monazite-bearing rocks. Tributaries to the two rivers have formed placers that are very high in monazite 4 miles upstream from the large flood plain. Four small flood plains have formed on the two rivers upstream from their confluence and within the belt. These flood plains are irregularly spaced at intervals of 2 or 3 miles along the rivers. Many small flood plains built up by tributaries to the rivers add substantially to the aggregate volume of alluvium in the drainage system。 Fairforest Creek. Fairforest Creek is the largest tributary to the Tygre River in the belt. The stream heads 5 miles west of Spartanburg, S, Co, crosses the southeast margin of the belt 9 miles from its headwaters, and joins the Tygre River outside the belt. Many of the placers formed by tributaries in the upper reaches of Fairforest Creek contain 15 to 30 percent of monazite in the concentrate. Stream sediments have been trapped along Fairforest Creek near the south east margin of the belt by constricted valley walls. This deposition has produred a series of one large and two intermediate flood plains which are so closely spaced along the stream that they practically form one continuous flood plain. Two large flood plains begin 2 miles farther downstream, but they are probably too fax from source areas to have minable quantities of monazite. There are relatively fow small flood plains in this drainage. 


\section{Pacolet River drainage}

The North Pacolet River heads in Henderson County, No Co, and the South Pacolet River rises in Greenville County, S。C. The two rivers rise in the Blue Ridge and join in Spartanburg County, S. C, , to form the Pacolet River a few miles inside the northwest margin of the belt. The Pacolet River passes through the belt. Tributaries emptyo ing into the North and South Pacolet Rivers drain areas essentially barren of monazite except for several small streams entering the rivers 3 miles upstream from their confluence. For 15 miles downstream from the junction of the North and South Pacolet Rivers placers formed by the tributaries have high tenors in monazite. Three of these tributaries are more than 6 miles long and lie wholly within the belt.

Flood plains on the Pacolet River inside the belt are continuous and relatively narrow; they have a nearly uniform width of 300 to 400 feet. At two places valleys widen to form intermediate flood plains. One of these flood plains is at the confluence of Island Creek and the Pacolet River in Spartanburg County, S。C. Four miles downstream from this flood plain, alluvium has accumulated to form another intermediate flood plain at the mouth of Turkey Hen Branch. Both of these flood plains are downstream from the mouths of tributaries that have very rich source placers of monazite.

Lawsons Fork Creek.- Lawsons Fork Creek is the largest tributary to the Pacolet River within the belt. Lawsons Fork Creek flows 22 miles across monazite-bearing rocks and joins the Pacolet River at the southeast 
margin of the belt in Spartanburg County, S。 Co For 4 miles upstream from its mouth the stream flows through a narrow valley. This valley opens out upstream into one large flood plain which is the largest on the Pacolet River drainage within the bèlt. Heavy-mineral concentrates in source placers on many of the tributaries to the Lawsons Fork Creek for a distance of 7 miles upstream contain 20 to 40 percent of monazte. The aggregate alluvium in small flood plains of tributaries to the Pacolet River in the beit oxceeds the alluvium in the relatively few large and intermediate flood plains in this drainage system. It is estimated that the total quantity of monazite is also greater in placers of the tributaries.

\section{Broad River drainage}

The Broad River heads in the Blue Ridge in Buncombe County, $N_{0} C_{0}$, flows eastward into Rutherford County, $\mathrm{N}_{0} \mathrm{C}_{0}$, and then southward parallel-. ing the Rutherford County = Polk County Iine. Monazite is in source placers feeding into the river from the north as far west as Cove Creek in western Rutherford County, but the tenors are very low and inconw sistent. Epidote is an abundant accessory in the heavy mineral suites obtained west of Rutherfordton. The tenor in monazite shows a general increase and a corresponding decrease in epidote in the source placers east of Cove Creek. South of Rutherfordton, Cleghorn Creek marks the eastern edge of this zone of increasing monazite and decreasing epidote. East of Cleghorn Creek monazite is consistently present in the concentrate. 
The southern tributaries to the Broad River in this area are low in monazite except for rare local concentrations. The west boundary of the monazite belt passes southward between the Green River and McKinney Creek roughly along the Rutherford County - Polk County line.

From McKinney Creek the Broad River flows eastward across Rutherford County into Cleveland County, NoC:; where it is joined by the Second Broad River and the First Broad River. At its junction with the First Broad River, the Broad River turns and flows south and southeastward into Cherokee County, S。C。 This course is maintained to the Coastal Plain at Columbia, S。Co, where the Broad River joins the Saluda River to form the Congaree River.

The east boundary of the monazite belt trends northeastward from the Pacolet River across Cherokee County to the Broad River following generally along U. S。 Route 29 through Gaffney, S。C. It intersects the Broad River at the mouth of Cherokee Creek and thence trends more toward the north, roughly following Buffalo Creek into North Carolina. This southeast boundary is sharp in Cherokee and Cleveland Counties。 South of the boundary in Cherokee County the heavy minerals in the source placers are barren of monazite and are dominated by staurolite.

Thus 30 the 50 miles of the river's length from its headwaters to Cherokee Creek are within the area of monazite-bearing source placers。 In addition, the entire 40 mile length of the First Broad River is within the belt, and 15 miles of the 30 mile length of the Second Broad River are in the area. 


\section{OFFICIAL USE ONLY}

72

Large and intermediate flood plains are along the Broad River; the most promising of these are at, or just downstream from, the east margin of the belt. One of these is at the mouth of Buffalo Creek in Cherokee County, S。C. It contains an estimated 18 million cubic yards of alluvium along 2 miles of the river (plate 10). Another is at the mouth of Sarratt Creek; it contains an estimated 8 million cubic yards of alluvium along 2 miles of river. Although the flood plains of the river are larger than those of its tributaries, none is outstanding through the core of the belt. On the west edge of the belt a flood plain at the mouth of Cleghorn Creek is estimated to contain 7 million cubic yards of alluvium along 3 miles of the river. Epidote has been carried great distances along the river and has been concentrated in these flood plains more readily than has monazite.

Southern tributaries to the Broad River. Thicketty Creek and the Green River, all the southern tributaries to the Broad River upstream from the Pacolet River are small streams with correspondingly small flood plains. Thicketty Creek drains most of western Cherokee County, S。C。, but only its headwater stretches, Beaver Dam Creek, Macedonia Creek, and Little Thicketty Creek, are in the monazite-bearing area. Concentrates obtained from source placers in these headwater tributaries contain 5 to 20 percent of monazite. Beaver Dam Creek has a narrow but continuous intermediate flood plain starting a mile upstream from its mouth and extending a mile up the main stream and a mile up Cold Creek. An intermediate flood plain on Macedonia Creek extends 1.5 miles upstream from its mouth. The flood 
plains on Little Thicketty Creek are all small, but several of these are joined above the mouth of Cowpens Creek to form an intermediate flood plain. Intermediate flood plains are developed on Thicketty Creek below the mouth of Beaver Dam Creek, and a large flood plain (plate 11), has developed on the main stream between U.S. Rioute 29 and State Route 18. This flood plain includes the mouths of Little Thicketty Creek and Limestone Creek.

Monazite is rare in the concentrates from the tributaries to the Broad River between Thicketty Creek and Cherokee Creek。 Concentrates from source placers on Cherokee Creek, Morgan Creek, Sarratt Creek, Ashworth Creek, Suck Creek, Horse Creek, and McKinney Creek contain 5 to 30 percent of monazite. With the exception of two intermediate flood plains on Cherokee Creek downstream from Providence Branch, which aggregate 5 million cubic yards along 3.5 miles of stream, all the flood plains on these streams are small. Monazite is rare in the Green River and its tributaries.

Northern tributaries to the Broad River.--The principal northern tributaries to the Broad River inside the monazite belt are Buffalo Creek, the First Broad River, Sandy Run Creek, and the Second Broad River.

Buffalo Creek.-Buffalo Creek rises in Lincoln and Cleveland Counties, N. Co, and flows 40 miles south to join the Broad River in Cherokee County, S。C。 Its lower 25 miles mark the east edge of the monazite belt. Eastern tributaries in the upper 15 miles are monazite.bearing. Numerous small flood plains in the upstream part of Buffalo Creek contain 5 to 70 percent of monazite in the concentrate and 


\section{OFFICIAL USE ONLY}

\section{4}

average 22 percent of monazite in the concentrate. An intermediate flood plain 8 miles from headwaters, drilled in the winter of $1951-52$, averaged 1.2 pounds of monazite to the cubic yard。 An intermediate flood plain 30 miles farther downstream nearly at the mouth of Buffalo Creek was drilled in the winter of $1952-53$. It averaged 0.3 pound of monazite to the cubic yard. Between these two areas are one large and four intermediate flood plains on the main stream. The large flood plain begins 2.5 miles downstream from U. So Route 74 in Cleveland County, $N, C_{c}$, and extends 5 miles downo stream. Western tributaries to Buffalo Creek are small. Eastern tributaries flowing from areas in the belt have many small and several intermediate flood plains. The largest tributaries enter along the southeastern part of Buffalo Creek and are barren of monazite。

Between Buffalo Creek and the First Broad River is the Boween River, a short stream 7.5 miles long near the east edge of the belt. Its course is marked by a single intermediate flood plain which totals about 8 million cubic yards of alluvium. Concentrates contain 3 to 24 percent of monazite and average 12 percent.

First Broad River.--The First Broad River heads in the South Moun tains in Rutherford County, NoCo, and flows 40 miles (60 miles as it meanders) southeastward to join the Broad River in Cleveland County, N。C. Throughout its length the First Broad River is in the monazite belt, as are its tributaries. The chief tributaries to the First Broad River are Beaverdam, Brushy, Knob, Hinton, Duncans, and Wards Creeks, and the North Fork. Extreme headwater tributaries, like the North Fork, are far 
enough west to pick up epidote from the wide area of epidotembearing rock in the western part of the belt. Once introduced, epidote is present in sediment of the First Broad River all the way to its mouth. Except for extrome headwater tributaries, all streams leading into the First Broad River have good percentages of monazite in concentrates from source placers. The concentrates are typical from Brushy Creek which range from 5 to 50 percent and average 20 percent monazite, and from Knob Creek, which range from 5 to 80 percent and average 25 percent. Downstream along tributaries the average monazite in concentrates decreases to 5 percent. The upstream 20 miles of the First Broad River have a succession of intermediate flood plains alternating with narrow gorges. North and northwest of Polkville, Cleveland County, $\mathrm{N}$, Co, the intermediate flood plains coalesce to form one of large size. From Polkville to the Broad River the stream is intrenched and has no large flood plain. Three of intermediate size are developed near Shelby, NoC。

Beaverdam and Brushy Creeks are respectively 8.5 and 12 miles in length. Each has mall folood plains along its full length; locally the small flood plains merge to form one of intermediate size on each stream。

Knob Creek rises near the Cleveland County - Burke County boundary, No Co, and flows 14 miles south to join the First Broad River. Its lower 4 miles are intrenched with scant development of flood plains. Three intermediate flood plains are in the middle reaches of the stream, and many small flood plains are along its headwaters. Locally source placers contain 25 pounds of monazite to the cubic yard, but the average 
in intermediate flood plains is about 1.6 pounds of monazite to the cubic yard。

Hinton, Duncans, and Wards Creeks are similar to Knob, Beaverdam, and Brushy Creeks in percentage of monazite in concentrates. Their gradients are steeper; small and intermediate flood plains are more widely separated along their courses. The North Fork, like other headwater tributaries to the First Broad River, has a steep gradient and generally small flood plains. One intermediate flood plain is developed about 2 miles upstream from its mouth.

Sandy Run Creek ${ }^{\infty}-$ Concentrates from small flood plains and source placers at the headwaters of Sandy Run Creek average 25 percent monazite。 An intermediate flood plain 2.5 miles downstream from headwaters was drilled in the winter of 1951 - 52. It averaged 1.6 pounds of monazite per cubic yard. This was the uppermost of a series of intermediate flood plains that extend 3 miles upstream and 3 miles downstream from the Rutherford County - Cleveland County line, N。C. Downstream from these flood plains is another intermediate flood plain which extends 2 miles up West Fork from the junction of that stream with Sandy Run Creek and Mayne Creek. Below this junction the flood plains are narrow and small. Second Broad River. $\cdots$ The Second Broad River heads in the Blue Ridge in McDowell County, NoC。 The river flows southeastward 15 miles through an area low in monazite and high in epidote. Intermediate and small flood plains along this stretch of the river, particularly near the Rutherford County - McDowell County line, contain some gold。 Cane Creek, a tributary to the Second Broad River, marks the west boundary of the 
monazite belt. Concentrates from source placer gravel east of Cane Creek contain more than 10 percent of monazite (table 7): concentrates taken west of Cane Creek contain no more than 5 percent mona zite except for those on Camp Creek (table 8). Several intermediate to large flood plains are developed along the river between the Rutherford County - McDowell County line and Puzzle Creek, but in these epidote is the dominant heavy mineral and the percent of monazite is low.

Table 7.. Concentrates from source placer gravel on tributaries to the Second Broad River east of Cane Creek.

\begin{tabular}{|c|c|c|c|c|c|c|c|}
\hline \multirow[t]{2}{*}{ Stream } & \multirow{2}{*}{$\begin{array}{l}\text { No. of } \\
\text { samples }\end{array}$} & \multicolumn{3}{|c|}{ Percent of Monazite } & \multicolumn{3}{|c|}{ Percent of Epidote } \\
\hline & & Minimum & Maximum & Aver. & Minimum & Maximum & Aver. \\
\hline $\begin{array}{l}\text { Robinson Creek } \\
\text { including Hunting } \\
\text { Creek and Heaveners } \\
\text { Creek }\end{array}$ & 18 & 5 & 26 & 12 & 0 & 0 & 0 \\
\hline Puzzile Creek & 5 & 22 & 45 & 34 & $\underline{0}$ & 0 & 0 \\
\hline Webbs Creek & 6 & 8 & 27 & 18 & 0 & 0 & 0. \\
\hline Milis Creek & 3 & 21 & 35. & 27 & 0 & 0 & 0 \\
\hline $\begin{array}{l}\text { Small tributaries } \\
\text { west of river and } \\
\text { south of Catheys } \\
\text { Creek }\end{array}$ & 8 & 2 & 33 & 20 & 0 & 2 & 0 \\
\hline
\end{tabular}


Table 8, mencentrates from source placer gravel on tributaries to the Second Broad River west of Cane Creek.

\begin{tabular}{|c|c|c|c|c|c|c|c|}
\hline \multirow[t]{2}{*}{ Stream } & \multirow{2}{*}{$\begin{array}{l}\text { No. of } \\
\text { samples }\end{array}$} & \multicolumn{3}{|c|}{ Percent of Monazite } & \multicolumn{3}{|c|}{ Percent of Epidote } \\
\hline & & Minimum & Maximum & Aver & Minimum & Maximum & Aver. \\
\hline Eane Creek & $\underline{1}_{4}$ & 0 & 22 & 5 & 3 & 22 & 13 \\
\hline $\begin{array}{l}\text { Lamp Creek } \\
\text { including } \\
\text { Little Camp Creek }\end{array}$ & 10 & 0 & 16 & 9 & 1 & 10 & 5 \\
\hline Catheys Creek & 8 & 1 & 8 & 3 & 3 & 13 & 2 \\
\hline Gilker Mill Creek & 13 & 0 & 14 & 2 & 1 & 18 & h \\
\hline Second Broad River & 10 & 1 & 3 & 2 & 2 & 12 & \\
\hline
\end{tabular}

The rich, small tributaries to the Second Broad River downstream from Catheys Creek and Robinson Creek hare only small flood plains. The largest and richest of these is Puzzle Creek. Intermediate flood plains are along Robinson Creek upstream from its junction with Heaveners Creek. The largest of these, estimated to contain 3.6 million cubic yards of alluvium along 1.3 miles of stream, is at this junction. Catheys Creek has intermediate flood plains near its mouth, and Cane Creek has a single large flood plain extending nearly its entire length. Both of these streams are low in monazite and high in epidote。

Floyds Creek, Richardson Creek, and Cleghorn Creek are tributary to the Broad River west of the Second Broad River and have many small flood plains. With the exception of the flood plain previously mentioned on 


\section{OFFICIAL USE ONLY}

the Broad River at the mouth of Cleghorn Creek, the three streams have no large or intermediate flood plains. There is less monazite in these streams than in those to the east along the Second Broad River, but monazite is consistently present。

Mountain Creek and Cove Creek have larger flood plains than the streams farther east, but monazite is scarce and erratically distributed in them。

\section{Catawba River drainage}

The Catawba River flows eastward and southeastward across the monazite belt in McDowell, Burke, Catawba, and Lincoln Counties, $\mathrm{N}$. C. Drainage to the Catawba River inside the belt is divided between two systems. These are drainage directly into the Catawba River and drainage into the South Fork, which flows southward and joins the Catawba River at the North Carolina - South Carolina boundary.

Catawba River tributaries.-.Twenty-two tributaries flow into the Catawba River in MaDowell, Burke, and Catawba Counties. Large flood plains are along only two of these streams. The two large flood plains are on South Muddy Creek in McDowell County and on Silver Creek in Burke County。

The large flood plain on South Muddy Creek (plate 12) is about 7 miles upstream from the junction of Muddy Creek and the Catawba River. South Muddy Creek is near the northwest margin of the belt where tenors in monazite are low. 
The headwaters of Silver Creek drain an area in Burke County in which the rocks are poor to good sources of monazite. The north end of the flood plain is about 1.3 miles upstream from the confluence of Silver Creek and the Catawba River (plate 13) in the west-central part of the monazite belt.

Intermediate flood plains in the Catawba River drainage are along North and South Muddy Creeks in McDowell County, along Silver Creek, Hall Creek, Baily Fork, and Hunting Creek in Burke County, and along Lyl Creek in Catawba County。 Lyle Creek flows eastward to the east margin of the belt. The headwater placers on all these streams except Muddy Creek are rich in monazite。

Small flood plains are developed along all tributaries to the Catawba River. In headwater areas in the central part of the belt heary mineral concentrates from these small flood plains contain up to 60 percent of monazite. The amount of monazite decreases toward the east and west margins of the belt.

South Fork tributaries.--The South Fork of the Catawba River is formed by the confluence of Jacob Fork and Henry Fork in Catawba County. Jacob Fork and Henry Fork rise in the South Mountaing in Burke County, $\mathrm{N}_{\circ} \mathrm{C}_{\circ}$ flow eastward, and are. inside the monazite belt throughout their lengths 。 The rocks drained by the headwaters of both streams and by most of their tributaries are rich in monazite。

There are no. large flood plains in the drainage of Jacob Fork and Henry Fork。 Intermediate flood plains are along each of the streams. The flood plain at the confluence of the two streams contains an estiw mated 8.7 million cubic yards of alluvium. 


\section{OFFICIAL USE ONLY}

81

Intermediate flood plains are developed along Indian Creek and Howards Creek in Lincoln County, N. C. The headwaters of each of these streams drain areas rich in monazite west of the South Fork. The area east of the South Fork in Lincoln County is outside the monazite belt.

Small flood plains are common in the South Fork drainage. Those in Burke County, western Catawba County, and northwestern Lincoln County receive drainage from headwater areas underlain by good source rocks. East of South Fork, in Catawba and Lincoln Counties, the margin of the belt is approached and the monazite in bedrock and in sediments decreases sharplyro

\section{Placers in the other districts}

\section{Yadkin River - Dan River district}

The area drained by the Yadkin and Dan Rivers in Surry and Stokes Counties, $\mathrm{N}_{0} \mathrm{C}_{0}$, and Patrick County, Va,g is low in monazite。 Parts of the area are barren of monazite. Consideration of flood plains in the Yadkin River - Dan River district in terms of economic placer concentrations of monazite is unwarranted。

\section{Oconee River district}

The Oconee River and the Middle Oconee River head in Hall County, Ga., and flow southward to join at the Oconee County - Clarke County line. Monazite is in the tributaries to these rivers west of the Middle Oconee River throughout Oconee County and as far north as Winder in Barrow County. 


\section{OFFICIAL USE ONLY}

82

In this area the two rivers are intrenched and actively cutting so that the larger flood plains are restricted to the upper reaches of tributary streams。

Concentrates from source placers along Bear Creek and Barber Creek in Barrow County contain 5 to 20 percent of monazite, and concentrates from Oconee County generally contain more than 10 percent of monazite.

Flood plains on Bear Creek are small but continuous. One intermediate flood plain is at the mouth of the stream. Continuous with this inter.. mediate flood plain are several of the same size on the Middle Oconee River, It is not likely that these flood plains on the Middle Oconee River contain much monazite. On MoNutt Creek a connected series of small and intermediate flood plains extends 6.5 miles downstream from headwaters. On Barber Creek a large flood plain extends from Eastville to the Oconee County - Barrow County line; where it narrows but continues to the headwaters of the stream for a total length of 10 miles. Butler Creek has small flood plains upstream from Watkinsville but none downstream from the town. Porters and Wildcat Creeks have small, continuous flood plains in their upper reaches. Several long intermediate flood plains are developed on Rose Creek.

Barrow, Falling, and Sandy Creeks in Oglethorpe County and Marburg, Cedar, Hawk, and Barbers Creeks in Barrow County contain very little monazite。 
OFFICIAL USE ONLY

83

Flint River district

The Flint River heads about 20 miles north of the area sampled in Pike and Spalding Counties, Ga. In these counties streams tributary to the Flint River drain only one area of monazite-bearing bedrock. That is the area drained by Flat Creek south of Zetella, Ga, Flat Creek has several small flood plains but none exceeds 1 million cubic yards of alluvium。

About 5 miles south of the area sampled, the Flint River flows across the strike of the Hollis quartzite. The quartzite, because of its resistance to erosion, has produced a graded reach upstream from its outcrop on the Flint River. Many streams tributary to the Flint River have low gradients and scant flow of water. The channel sediments are thick accumulations of mud. Many of these streams head in swamps. These features make sampling of placers in the Flint River district more difficult than in the other districts.

\section{Chattahoochee River distriat}

The headwaters of the Chattahoochee River are in the Blue Ridge about 150 miles northeast of the area sampled in Troup, Harris, and Meriwether Counties, Ga. Only one area of monazite-bearing source rocks is drained by streams tributary to the Chattachoochee River. A f'ew samples taken from the headwaters of Flat Shoal Creek and its tributaries contain up to 10 percent of monazite in the heavy-mineral concentrates. Near the headwaters of these streams, where monazite 
is commonly concentrated, are several flood plains none of which exceeds I million cubic yards in volume. There are no large or intermediate flood plains along Flat Shoal Creek.

Along the downstream parts of Yellow Jacket and Long Cane Creeks are flood plains that exceed 10 million cubic yards in volume. In the upper reaches of both of these streams are two intermediate flood plains, but neither drain areas of monazite-bearing bedrock. Mountain Creek" which is subsequent to the structure of Pine Mountain, has developed a continuous flood plain from its headwaters downstream for 12 miles. The total volume of alluvium is estimated to exceed 20 million vubic yards, Concentrates of heavy minerals from Mountain Creek contain abundant kyanite but have less than 5 percent of monazite。

A.long the north slopes of Pine Mountain are several accumulations of Tertiary (?) gravel (Hewett and Crickmay, 1937, pl。1)。 The source of the small amounts of monazite in this gravel is unknown. Associated with the gravel are small lenses of kaolin and bauxite. On the upper. s.lopes of Pine Mountain, 400 to 500 feet above the gravel, is a higher accumulation of Tertiary (?) gravel. The higher gravel contains good concentrations of rutile but scant monazite.

\section{Placers in trunk drainage}

Deposits of monazite in the trunk drainage between the western belt and the Coastal Plain were not studied during reconnaissance. Trunk streams northwest of the Coastal Plain and north of the Catawba River, as the Pee Dee, Yadkin, Dan, and Roanoke Rivers, can 
be dismissed as remotely possible sources for monazite because only a small fraction of their total drainage area is in monazitembearing, terrane and part of that is notably low in monazite. The Catawba, Wateree, Broad, Saluda, and Congaree Rivers tap the largest source areas of monazite of any trunk streams leading from the belt. Southwest of the Saluda River and northwest of the Coastal Plain, the Oconee River drains the best source areas. The Savannah, Ocmulgee, Flint, and Chattahoochee Rivers drain poor or proportionately sma.ll areas of monazitembearing rock. The system of rivers joining southeast of Columbia, So Co, to form the Santee River are the most favorable trunk streams to study for possible accumulations of monazite。

The low tenor of fine grained sediment in flood plains of trunk streams was shown by drilling on the Broad River in Cherokee County $\mathrm{S}_{\circ} \mathrm{C}_{\circ}$ where the ground averaged about 0.27 pound of monazite to the cubic Jard (field estimate by the U。S。Bureau of Mines). Surficial reconnaissance of flood plain. silts would be fruitless. Thick sequences of coarse grained fluvial sediments should be the best hosts for detrital monazite in the trunk drainage. Comminuted monazite from the western monazite belt can be expected in gravel downstream toward the Santee River。Grab samples from commercial gravel pits in the flood plains of the trunk streams will indicate if sedimentation has favored concentration of monazite in downstream gravel. 


\section{OFFICIAL USE ONLY}

\section{6}

\section{Possible byproducts of placers}

It is unlikely that monazite can be brought into production in the western monazite belt without the aid of byproducts. Sand and gravel should find a ready market in this heavily-populated region。 Gold would have its usual ready sale, but only locally can a few cents in gold be found in a cubic yard of ground. The associated heavy minerals for which some use might conceivably be found are garnet, ilmenite, rutile, zircon, kyanite, and sillimanite. The garnet has been reported (Pratt, 1904, p。 1168) to have good abrasive properties. The ilmenite averages low in total $\mathrm{TiO}_{2}$. Rutile rarely makes up as much as 10 percent of the total heavy-mineral fraction. Few larger placer areas contain more than 3 percent of zircon in the concentrate. Kyanite and sillimanite of non-strategic quality make up 5 to 25 percent of some concentrates. Mountain Creek in the Chattahoochee River district contains about 25 pounds of kyanite to the cubic yard. Search for tungsten, tin, columbite, and tantalite in concentrates from the belt has been unrewarded。 


\section{OFFICIAL USE ONLYY}

87

SUMMARY AND CONCLUSIONS

Conclusions drawn at the present stage of the investigation are tentative and indicate current trends of thought. Results of a long-term study do not follow immediately upon completion of field work. Time must be spent to corollate field data, to review laboratory reports, and to study results from churn drilling by the U.S. Bureau of Mines before final conclusions can be made.

Some tentative conclusions are introduced below。

\section{Monazite belt}

A belt of monazite-bearing crystalline rocks is the source of detrital monazite in streams in the western Piedmont of the southeastern states. Margins of the belt in places are sharply defined by an abrupt cut off of monazite in streams of small distributive province, and in other places are marked by a zone of gradually-diminishing monazite, or a zone of irregularly spaced monazite-bearing areas that alternate with barren areas. These barren areas increase in size and coalesce where the monazite-bearing areas are narrow. Some places inside the belt are barren or low in monazite. The most likely sites for monazite placers in the western Piedmont are in the belt or downstream from its southeast margin. 


\section{OFFICIAL USE ONLY}

88

\section{Tenor of crystalline rocks}

The amount of monazite in the belt is greatest in areas underlain by rocks of high metamorphic rank that have been widely intruded by granitic material. Whe re present, monazite makes up 0.000006 to 0.034 volume percent of the rock. At one locality the crystalline rock cono tained about 1 percent of monazite. No area is known in the western belt where monazite might profitably be recovered from the crystalline rock。

\section{Role of saprolite}

Saprolite is estimated to underlie 80 percent of the belt. It is easily eroded, permitting streams to cut broad, flat valieys. Monazite in saprolite is easily liberated for eventual fluvial concentration by every process of erosion operative in the district. Against these factors tending to concentrate the heavy minerals must be opposed the fllow of predominantly fine-grained detrital particles from saprolite to the streams to bury accumalations of monazite beneath 2 low-tenor mantle of 1 ine sand, silt, and clay.

\section{Associated minerals}

Associated heavy minerals in concentrates from stream deposits of the belt rellect the composition of crystalline rocks in the distributive province, conditions of transportation, and relative rates of deposition. Locally recoverable gold is probably the only associated mineral that 


\section{OFFICIAL USE ONLY}

89

would have a ready sale. Associated minerals for which some use might be found are garnet, ilmenite, rutile, zircon, kyanite, and sillimanite. No placer concentrations of minerals containing niobium, tantalum, tungsten, or tin have been found in the belt.

\section{Age of placers}

Monazite placers in the flood plains of the belt are in stream sediments that are post wisconsin in age. These sediments can be divided into a lower, pre-agricultural sequence, and an upper, modern sequence deposited since agriculture was established. Some prewisconsin terrace gravel of small areal extent is exposed.

\section{Sequence of sediments}

Finer-grained sediments are thicker in areas of low relief with gentle stream gradients; coarser-grained sediments thicken in areas of greater relief and steeper gradients. This relation is evident at all scales from the small tributary stream to the belt as a whole. The average thickness of fineragrained sediment is greater in the downstream reaches of all drainage, is greater in the eastern than in the western part of the belt, and is greater in the southern than in the northern part of the belt. It is thought that this overall uniformity in sedimentation reflects the regional similarities of saprolitized crystalline rocks and climatic environment since the end of Wisconsin time. 
OFFICIAL USE ONLY

90

Tenor of monazite related to grain size and sorting of sediments

Monazite is more abundant in coarser sediments and in poorly sorted sediments than it is in finer and well-sorted sediments. Gravel and coarse sand toward the base of the fluvial sediments contain most of the monazite in the alluvium. In the larger flood plains at places where the average tenor exceeds 2 pounds of monazite to the cubic yard two conditions obtain: (I) more than 15 percent of the total thickness of alluvium is coarse sand and gravel, and (2) tenor of the fine-grained overburden is higher than average.

Tenor of monazite related to size and position of flood plains

The larger the flood plain and the farther it lies from the source of monazite in the belt, the lower is the tenor of the alluvium.

\section{Role of colluvium and the possibility of eluvial deposits}

Colluvial deposits that overlie saprolite and hard rock range in age from prewisconsin to late Recent. They serve as an intermediate host for monazite between crystalline rock and the stream deposits. Reworking of colluvium by streams forms a higheretenor alluvium than does fluvial sorting of sediment derived directly from saprolite. Some colluvial deposits represent an enrichment in monazite of 15 times over the tenor of saprolite. Such enriched colluvial deposits are eluvial placers. No study of eluvial placers has been made: but one appears justified. 
OFFICIAL USE ONLY

91.

\section{Terrace deposits}

Widely scattered deposits of terrace gravel have been noted throughout the belt. Commonly they are small and are covered by colluvium. An exception is some large areas thinly veneered with exposed Tertiary (?) gravel in the Chattahoochee River district. None of the deposits of higher gravel appears suitable as a source for monazite.

\section{Deposits in trunk drainage}

Only thick sequences of coarse-grained sediment in the trunk drainage should be studied. Tenors of the fine-grained sediment will be very low. The most favorable areas for study should be commercial gravel pits on the system of rivers joining southeast of Columbia, $S_{0} C_{0}$. and on the Oconee River in Georgia.

\section{Mining in the western belt}

No large flood plain has been found in the belt that will economically support dredging. It is doubtful if any large flood plain in the belt would make more than a marginal venture under the present market。 Small to intermediate flood plains with better ground than the large flood plains are common, but they cannot be mined unless strategically placed purchasing offices able to take rough concentrate are established in the district. Byproduct output from operating sand and gravel pits would be faced with the same problem in sale of rough concentrate. 


\section{OFFICIAL USE ONLY}

92

RECOMMENDATIONS

\section{Physical exploration}

It appears that none of the large flood plains explored in the monazite belt averages more than I pound of monazite to the cubic yard. There is no reason to believe that similar large flood plains elsewhere in the belt will be richer in monazite. Should there be any further interest in low-tenor ground, exploration could be speeded by working in the summer when the season is drier and the flood plains are more accessible than they are during the winter. The areas listed on the following pages are most favorable for physical exploration. Further physical exploration is not planned by the Geological Survey at the present time.

Five large flood plains, lettered A through E on plate 14, are described below. Tenors average about 0.5 pound of monazite to the cubic yard of alluvium.

Unless there is interest in large-volume ground averaging 0.5 pound of monazite to the cubic yard or intermediate-volume ground ranging in tenor from 1 to 2 pounds of monazite to the cubic yard, additional exploration in the western monazite belt is not recommended.

\section{Enoree.River}

Stream sediments in the valley of the Enoree River between the Spartanburg County Route 118 crossing the Ligon's Bridge in Spartanburg and Laurens Counties, So $C_{0}$, have a volume of 12.4 million cubic yards (A, plate 14)。Valley-fill occurs as a flood plain which ranges in 
width from 150 to 1,600 feet. One mile upstream from the mouth of Durbin Creek the Enoree River flood plain attains its maximum width. Eight holes were drilled in this part of the flood plain with an auger. Total thickness of alluvium in the eight holes was 105 feet of which 7 feet are gravel, 51.5 feet are sand, 19 feet are silt, and 27.5 feet are clay. At the upper end of this flood plain the river drains 270 square miles of monazite-bearing rock。 Gilder Creek, Rocky Creek, and many small, nameless streams in this drainage area have placers containing heavy mineral concentrates ranging from 5 to 40 percent of monazite.

\section{South Tygre River}

For 4 miles downstream from State Route 417 crossing in Spartanburg County aliong the South Tygre River are 14.1 million cubic yards of a.luvium ( $B$, plate 14) in three flood plains separated by constrictions in the valley walls. The minimum width of the constrictions is 150 feet and the maximum length is 1,100 feet。 Auger drilling penetrated 230.5 feet of alluvium in 10 holes. This alluvium comprises 15.5 feet of gravel, 1.12 .5 feet of sand, 51.5 feet of silt, and 51 feet of clay. For 20 miles upstream, tributaries to the South Tygre River drain monazite-bearing rocks。 Monazite from placers on several of these tributaries ranges from 20 to 40 percent of the concentrate.

\section{Fairforest Creek}

A flood plain on Fairforest Creek between the crossing of U. S. Route 221 and the mouth of Kelsey Creek in Spartanburg County, S。Cog contains 22.7 million cubic yards of alluvium ( $C$, plate 14 ). This flood plain ranges in width from 200 to 1,400 feet. Depth to bedrock, as 
indicated by 10 auger drill holes, averages 16 feet. Of this average depth $I$ foot is gravel, 4.5 feet is sand, 4.5 feet is silt, and 6 feet is clay. Monazite is found in the stream sediments of all the tribataries upstream from this flood plain; many of the concentrates contain 15 to 20 percent of monazite.

\section{Lawsons Fork Creek}

The largest flood plain on the Pacolet River drainage system inside the belt is on Lawsons Fork Creek, 4 miles upstream from the junction of Lawsons Fork Creek with the Pacolet River in Spartanburg County, S。C。, ( $D_{3}$ plate 14)。An auger was used to drill 11 holes in the flood plain. Calculations based on the results of this drilling and on interpretation of aerial photographs indicate that the flood plain contains 12.2 million cubic yards of alluvium. Of the total 162 feet of alluvium logged in the 11 holes 13 feet is gravel, 57 feet is sand, 64.5 feet is silt, and 27.5 feet is clay. Heavy mineral concentrates from many of the source placers upstream from this flood plain contain 20 to 40 percent of monazite。

\section{Buffalo Creek}

The upstream end of a flood plain on Buffalo Creek, Cleveland County, N。C. (E, plate 14 ) is 2.5 miles south of U。 So Route 74 where that road crosses the stream 4.5 miles east of Shelby, NoC. The flood plain extends 5 miles downstream, has an area of 3.1 million square yards, and an estimated volume of 19 million cubic yards of alluvium averaging 


\section{OFFICIAL USE ONLY}

95

35 percent of coarse sand and gravel. It is estimated that the sediments average 15 pounds of concentrate per cubic yard and that 5 percent of the concentrate is monazite. Dense vegetation covers 85 percent of the surface area.

\section{Intermediate-sized flood plains}

The highest-grade flood plains between 1 and 5 million cubic yards in volume have tenors that range from 1 to 2 pounds of monazite per cubic yard. The highest grade flood plains between 5 and 10 million cubic yards in volume have tenors that range from 0.5 to 1 pound of monazite per cubic yard. Intermediate flood plains are more common than large flood plains. Among them the following nine, lettered $\mathrm{F}$ through $\mathrm{N}$ on plate 14 , appear likely to range in tenor from 0.5 to 2 pounds of monazite to the cubic yard, with the higher average tenors in the smaller-rolume deposits.

\section{Broad Mouth Creek}

Broad Mouth Creek in Anderson County, $\mathrm{S}, \mathrm{C}_{\circ}$, has one intermediate flood plain ( $G$, plate 14 ) estimated to contain 3 million cubic yards of allurium. The flood plain is 2 miles northeast of Honea Path, S。C., 4 miles upstream from the mouth of the stream and just north of U. S. Route 76. Five auger holes drilled in the flood plain average 15 feet to bedrock and show 8 percent of gravel, 47 percent of sand, 5 percent of silt, and 40 percent of clay. Concentrates from nearby small tributary streams contain up to 50 percent of monazite, but the headwaters of the stream drain an area of monazite-free bedrock. 


\section{OFFICIAL USE ONLY}

96

Big Beaverdam Creek

One continuous flood plain in the downstream part of

Big Beaverdam Creek (F, plate 14 ), Anderson County, S。Cog contains an estimated 10 milition cubic yards of alluvium. This flood plain lies about 3 miles upstream from the junction with the Tugaloo River。 State Route 80 crosses the downstream part of the flood plain 25 miles west of Anderson, S. Co Eight auger holes drilled in the flood plain have an average depth of 12.5 feet of which 5 percent is gravel. 43 percent is sand, 26 percent is silt, and 26 percent is clay. Tributary streams to the flood plain drain bedrock low in monazite。 Heavy mineral concentrates containing up to 25 percent of monazite were obtained from streams tributary to Big Beaverdam Creek about 7 miles upstream from this flood plain. The area is low in monazite; it is expected that this flood plain will average no more than 0.5 pound of monazite to the ubic yard.

\section{Durbin and South Durbin Creeks}

There are 9.8 million cubic yards of alluvium in two flood plains along the lower reaches of Durbin and South Durbin Creeks ( $H$, plate 14 ) in Laurens County, S。C。 These flood plains are separated by a constric... tion in the valley walls 50 to 100 feet wide and 800 feet long immediately downstream from the confluence of the two streams. The flood plain downstream from the constriction reaches its greatest width near the junce tion of Durbin Creek with the Enoree River. Upstream from the constriction 
flood plains of the two streams coalesce and attain their maximum width of 950 feet.

Eight auger holes drilled in the flood plain on South Durbin Creek indicate that the sediments have an average depth of 15.5 feet of which $I$ foot is gravel, 9 feet is sand, 3 feet is silt, and 2.5 feet is clay。 Monazite is present in stream sediments of all the tributaries to South Durbin Creek. Several of the tributaries have source placers in which the heavy mineral concentrates contain 10 to 20 percent of monazite. Three auger holes drilled in the flood plain of Durbin Creek average 10.2 feet in depth of sediment. This average depth comprises 0.7 foot of gravel, 3.3 feet of sand, 1.7 feet of silt, and 4.5 feet of clay. Source placers are not as rich in monazite in the Durbin Creek drainage as they are in the South Durbin Creek drainage. Heavy mineral concentrates from the richer placers of the Durbin Creek drainage contain 5 to 10 percent of monazite.

Pacolet River

The Pacolet River has deposited 10 million cubic yards of alluvium between the mouth of Casey Creek and the point where South Carolina: Route 31 crosses the Pacolet River $\left(J_{9}\right.$ plate $1_{4}$ ) in Spartarburg County, S。C。Alluvium is in a long, continuous flood plajn 300 to 400 feet wide that widens to 700 feet for 1,500 feet along the river near the mouth of Island Creek. Six auger holes drilled in the flood plain have an average depth of 19.4 feet. Only one of the six holes shows gravel; in that hole the gravel is 2.5 feet thick. Total thickness 


\section{OFFICIAL USE ONLY}

98

of sediments drilled is 116.5 feet of which 2.5 feet is gravel, 66.5 feet is sand, 26.5 feet is silt, and 21.0 feet is clay。

Many os the source placers upstream from this flood plain are very rich in monazite. Heavy mineral concentrates from many of these placers contain 25 to 40 percent of monazite. Monazite is particularly abundant on Casey and Cherokee Creeks.

Two miles downstream from the lower end of the flood plain described above, sediments have accumulated to form an intermediate flood plain ( $I_{s}$ plate $I_{4}$ ) containing 5 million cubic yards of alluvium. This flood plain extends 2 miles downstream on the Pacolet River from the bridge on South Carolina Route 30 in Spartajiburg County. Fours auger holes drilled in this flood plain showed an average depth of 17 feet of sediment. Totals of the sediments in the four holes drilled are 1 foot of gravel, 41.5 feet of sand, 15 feet of silt, and 11.5 feet of clay. This flood plain lies athwart the southeastern margin of the monazite belt. A.lthough heavy-mineral concentrates of source placers in the vicinity of this flood plain contain less than 5 percent of monazite, alluvium in the flood plain has been contributed by streams draining 90 square miles of monazite-bearing rocks. These two areas on the Pacolet River average no more than 0.5 pound of monazite to the cubic yard。 


\section{Cherokee Creek}

Two intermediate flood plains near the mouth of Cherokee Creek in Cherokee County, So $\mathrm{C}_{2}\left(\mathrm{~K}_{2}\right.$ plate $\left.\mathrm{I}_{4}\right)$ are separated by a short shoal at the Southern Railway bridge 4 miles northeast of Gaffney, S。C. The flood plain west of the bridge is estimated to contain 2.7 million subic yards of alluvium, and the flood plain southeast of the bridge is estimated to contain 2.6 million cubic yards of fill. Both of these flood plains have been cleared for farming. Auger drilling indivates an average depth of 13 feet of which 10 percent is gravel and 30 percent is sand. Consentrates from gravel in the area of these flood plains range widely in amount of contained monazite with the maximum of 30 persent.

\section{Robinson Creek}

At the junation of Robinson Creek and Heaveners Creek in Rutherford County, No Coy is a flood plain estimated to sontain $?$ 3.6 milition cubic yards of alluvium along 1.3 miles of stream ( $($, plate 14). This flood plain is continuous with four others extending 3.2 miles upstream and aggregating 4.9 million cubic yards。 The area is 3.4 miles by road north of Bostic, $N$. C. The flood plains have been cleared for farming. They average 14 feet in depth of which 30 percent is sand and gravel. Concentrates from source placers contain 9 to 26 percent of monazite. 


\section{OFFICIAL USE ONLY}

100

\section{Junction of Henry Fork and Jacob Fork}

The junction of Henry Fork and Jacob Fork $\left(M_{2}\right.$ plate 14$)$ is 5.9 miles south and 1.3 miles east of Hiekory in Catawba County, N。C.g and 0.7 mile north of the bridge where State Route 10 crosses the South Fork. The flood plain has an estimated area of 1.4 million square yards and contains an estimated 8.7 milizion cubic yards of alluvium.

A more or less continuous flood plain extends downstream along South Fork from a point 0.4 mile south of the junction of Henry Fork and Jacob Fork. This flood plain is about 3.5 miles long and 750 feet in average width. Alluvium in the flood plain has an estimated average thickness of 21 feet.

\section{Henry Fork}

A flood plain of intermediate size, 5.2 miles west of Newton, N。C. on the Henry Fork $\left(\mathrm{N}_{2}\right.$ plate $\left.\mathbf{1 4}_{4}\right)$ in Catawba County, $\mathrm{N}_{0} \mathrm{C}_{0}$, has an estimated volume of 5.4 million cubic yards of alluvium which has an average depth of 20 feet. Eight auger holes drilled in the flood plain show that gravel and coarse sand make up 20 percent of the alluvium.

\section{Subordinate studies}

The following descriptions point out the fields of study in which additional work. would be most fruitful. The Geological Survey does not plan to undertake these studies at this time。 


\section{OFFICIAL USE ONLY}

101

Eluvial placers

Eluvial placers containing about 2 pounds of monazite to the cubic yard can be found in colluvium of the interstream areas in the belt. Most such areas are small; some may be intermediate in size。

A study of colluvial deposits in the interstream areas in one-fouroth of a 15 minute quadrangle could be made in 24 man months. The area studied should be in the western monazite belt, should have modern topographic coverage, and should have detailed geology of bedrock already completed. The Shelby quadrangle, $\mathrm{N}_{0} \mathrm{C}_{0}$, is the only area in the belt that meets these requirements.

Examination of erosion gullies would give first estimates of the nature, thickness, and area of the colluvial mantile. Selected colluvial deposits could be sampled by auger drilling. Colluvial deposits are elayey and hold well on the auger. Generally there is no ground water to cause holes to collapse. All cuttings from the auger drill could be concentrated and tenors of the deposits calculated from the samples.

Colluvial deposits underlie hillsides and divides that have good agricultural value. Current selling prices for this type of land range. from $\$ 100$ to $\$ 200$ per acre.

\section{Study of suitable mining methods}

A study of mining methods adapted to the size and position of the placer deposits should be made. Small and intermediate flood plains are not suited for dredging, but might successfully be worked by small operaw tions in headwater areas if a local market took rough concentrates. 


\section{OFFICIAL. USE ONLY}

102

Study of trunk drainage

Grab sampling of commercial gravel pits on trunk drainage leading to the Santee River and on the Oconee River would show how much monazite has accumulated in fluvial gravel downstream from the belt.

\section{LITERATURE CITED}

Becker, G. F。, 1895, Gold fields of the southern Appalachians: U。 S. Geol. Survey l6th Ann。Rept。g pt。3, po 25l--33l。

Cain, So A, 1944, Pollen analysis of some buried soils, Spartanburg County, South Carolina: Terrey Botanical Club Bull。, v。 7l, no。, p。 1l--22。 Etheridge, $R_{0} B_{\circ}$ and Riley, $W_{0} H_{0}, 1948$, Hydrologic data on the Yadkin - Pee Dee River basin 1866 - 1945: North Carolina Dept。 of Conservation and Development, Division of Water Resources and Engineer ing, unnumbered report.

Genth, F。A. 2891, The minerals of North Carolina, U。 S。Geol, Survey, Bul1. 74 。

Griffitts, $W_{0} R_{0}$, and Overstreet, $W_{0} C_{0}, 1952$, Granitic rocks of the west.. ern Carolina piedmont: Am。Jour.Sci., vo 250, p. 777-789.

Happ, S。C。g Rittenhouse, Gorden, and Dobson, G。Co, 1940, Some principles of accelerated stream and valley sedimentation: $U$ 。 $S_{0}$ Dept。 of Agriculture Tech。Bull.695.

Hewett, D。F。, and Crickmay, G。Wo, 1937, The-warm springs of Georgia, their geologic relations and origin, a summary report: U. S. Geol. Survey Water-Supply Paper 819.

Hunter, Co $E_{0}$, and White, W。 Ao, 1946, Occurrences of sillimanite in North Carolina: North Carolina Dept。 of Conservation and Development, Division of Mineral Resources Information Circ. 4. 


\section{OFFICIAL USE ONLY}

103

\section{LITERATURE CITED-.-Continued}

Keith, Arthur, and Sterrett, D. Bo, 1931, Description of the

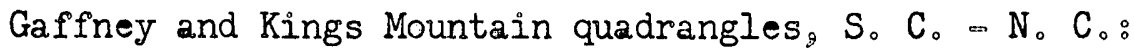
U.S.Geol。 Survey Geol.Atlas, folio 222.

Kesler, T。 L。 1944, Correlation of some metamorphic rocks in the central Carolina piedmont: Geol.Soc.America Bull。, 55, p. $755-782$ 。

LeGrand, $H_{0} E_{0}$, and Mundorff: M。 J。, 1952, Goology and ground water in the Charlotte area, North Carolina: North Carolina Dept。 of Conservation and Development, Division of Mineral Resources Bull。 63. Mertie, J。 Bo Jro, 1953, Monazite depositscofthe southeasters Atlani, L statesil. U. S. Geol, Survey Ciroc。237.

Mundorf $f_{9}, M_{0} J_{0}, 1948$, Geology and ground water in the Greensboro area. North Carolina: North Carolina Dept, of Conservation and Development, Division of Mineral Resources Bull. 55.

Pardee, J。 $\mathrm{T}_{0}$, and $\mathrm{Park}_{9} \mathrm{C}, \mathrm{F}_{0} \mathrm{Jr}_{\circ}, 1948$, Gold deposits of the southern piedmont: U。S.Geol. Survey Prof'。 Paper 213.

Pratt, J。H。, 1904, Monazite and zircon: Min。 res。 U。S., 1903, p. $1163-1170$. 1916, Zircon, monazite, and other minerals used in the production of chemical compounds employed in the manufacture of lighting apparatus: North Carolina Geol。 and Economic Survey Bull. 25. Sloan, Earl, 1908, Catalogue of mineral localities in South Carolina: South Carolina Geol。 Survey Bull。2。 


\section{OFFICIAL USE ONLY}

104

\section{LITERATURE CITED--Continued}

Sterrett, D。 B。, 1907, Monazite and zircon: Min。 res。U。S。, 1906, p. 1195-1209。

Stose, G。Wo, 1928, Geologic map of Virginia: Virginia Geol。 Survey。 1939, Geologic map of Georgia: Georgia Division of Mines,

Mining and Geology。

Watson, $\mathrm{T}, \mathrm{L}, 91902, \mathrm{~A}$ preliminary report on a part of the granites and gneisses of Georgia: Georgia Geol。 Survey Bull。9A。 1910, Granites of the southeastern Atlantic states:

U.S.Geol。Survey Bull。 426。

Anonymous, 1951, Farm, farm characteristiss, farm products:

U. S。 Bureau of the Census, Pretiminary 1950 ensus of agriculture.

\section{UNPUBLISHED REPORTS}

Overstreet, $W_{0} C_{0}, 1952 a$, Areas in the western monazite belt,

North and South Carolina, recommended for physical exploration by the U. S. Bureau of Mines: U。 S。 Geol. Survey Trace Elements Memo。Rept。502。

1952b, Further areas in the western monazite belt

of South Carolina recommended for physical exploration by the U. S. Bureau of Mines: U.S.Geol. Survey Trace Elements Memo. Rept。539。 
OFFICIAL USE ONLY

105

UNPUBLISHED REPORTS --Continued

Overstreet, $W_{0} C_{0}$, and Theobald, $\mathrm{P}_{0} \mathrm{~K}_{0}, \mathrm{Jr}, 2$ 1952, Progress report on investigations of southeastern monazite placers: U。S.Geol。 Survey Trace Elements Memo. Rept.283.

Sterrett, D。 B。, 1912, Geology of the Iincolnton quadrangle, U.S.Geol。Survey。

Yates, $R_{0} G_{0}$, Griffitts, W。 Ko, and Over street, W。 Co, in preparation, Geologic map of the Shelby quadrangle, N。C: U。S。Geol。 Survey

OFFICIAL USE ONLY 
U. S. Geological Survey Library

Denver Branch

14 